\title{
Going Viral: Designing Bioactive Surfaces with Bacteriophage
}

A Review submitted to:

Colloids and Surfaces B

May 25, 2014

ZEINAB HOSSEINIDOUST ${ }^{1}$, ADAM L. J. OLSSON ${ }^{1}$, and NATHALIE TUFENKJI*

Department of Chemical Engineering, McGill University,

Montreal, Quebec H3A 0C5, Canada

${ }^{1}$ A.L.J.O and Z.H. contributed equally to this work 


\begin{abstract}
Bacteriophage-functionalized bioactive surfaces are functional materials that can be used as antimicrobial surfaces in medical applications (e.g., indwelling medical devices or wound dressings) or as biosensors for bacterial capture and detection. Despite offering immense potential, designing efficient phage-functionalized bioactive surfaces is hampered by a number of challenges. This review offers an overview of the current state of knowledge in this field and presents a critical perspective of the technological promises and challenges.
\end{abstract}




\section{INTRODUCTION}

Bioactive surfaces are defined, for the purpose of this review, as substrates functionalized with specific recognition elements, used to detect, capture and/or deactivate microorganisms/analytes of choice. These substrates can find applications in biosensors (on platforms such as surface plasmon resonance sensors [1], quartz crystal microbalances [2], high throughput lab-on-chip systems [3], paper diagnostics and dip-stick assays [4, 5], etc.) or as antimicrobial/antibiofilm surfaces in applications such as food packaging [6], indwelling medical devices (implants, stents, catheters) [7], wound dressings [8], antibacterial wipes, water treatment membranes [9] and coatings on surfaces in medical settings $[10,11]$. Although a rich and interesting field of science, the subject of biotemplate design by virus/phage immobilization/patterning on substrates is beyond the scope of this text. The interested reader can consult a number of comprehensive reviews on the subject [12-19].

Bacteriophages (phages) are viruses that infect bacteria [20, 21]. Phages are the most abundant biological entity on earth and, being obligate parasites, propagate themselves by hijacking the host machinery [22]. They can have a broad host range, infecting several strains or species of bacteria [23], or infect a specific host, even down to a single bacterial strain [24]. A phage virion usually consists of a protein envelope (some also contain lipids in their envelope) encasing the genome, which can be a single or double stranded DNA or RNA molecule [25]. A phage virion may have a range of different shapes and sizes including tailed, filamentous, and icosahedral (Figure 1) [26]. A phage infects its host bacterium by first attaching its "capture proteins" to specific receptors on the host cell surface (e.g., lipopolysaccharide (LPS), pili, etc.) [27]. Phage capture proteins can be

located symmetrically all around the virion [28] or located asymmetrically on one vertex [29], on a pole (filamentous phages) [30] or at the tip of tail fibers (tailed phages) [31]. Once attached to 
the host bacterium, phage injects its genome into the host and either takes over host machinery immediately and starts propagating (lytic phage), or the viral genome gets incorporated into the host DNA and stays dormant (lysogenic or temperate phage). The lytic life-cycle ultimately leads to host destruction, except for some filamentous lytic phage which only decrease host growth rate [32]. The genome of a temperate phage is passed on to daughter cells during bacterial replication, maintaining the lysogenic lifestyle. Certain environmental triggers (e.g., heat, UV radiation, chemicals, etc.) can cause a switch from the lysogenic to the lytic lifestyle [33, 34].

All phages have the potential to be used as specific recognition moieties in designing bioactive surfaces. Compared to other biological agents that provide similar specific interaction for pathogen capture/detection (e.g., antibodies), phage offers the advantage of having a longer shelf life and being cheaper and more humane to produce. Most lytic phage also offer the dual functionality of capture and destruction of the host. Compared to other bactericidal agents (e.g., antibiotics, antimicrobial peptides, silver nanoparticles, chemicals, etc.), phage offer the advantage of specificity. This characteristic could be very beneficial in applications such as food packaging. Food-borne infections continue to claim lives and cause significant economic loss in many developed countries [35]. Broad action biocides must be used with caution in these settings because the taste, odor and texture of many food products depend on the presence of "good" bacteria. Thus, selective biocides are of particular interest. The same argument holds for many indwelling medical devices which must not disturb the body's microbiome, the collection of microorganisms living in our body that is responsible for maintaining physiological balance as well as the body's immunity towards infections [36]. Furthermore, phages are innocuous to humans, animals and plants, which is an added advantage over many biocides currently in use [37, 38]. Bacteriophages exist all around us in the environment and even in our bodies. Because they 
have evolved over billions of years with their host bacteria, when the host develops resistance to the phage, the phage can mutate to develop the ability to infect its host, leading to a constant evolutionary arms race [39-41]. Thus, novel phages can constantly be isolated from the environment to tackle new infections.

To use bacteriophages for designing bioactive surfaces, there exist several challenges that must be addressed. Firstly, to design a bioactive surface with high efficiency for use as either a biosensor or an antimicrobial surface, the immobilized phage must retain its infectivity. Moreover, for biosensing applications, a high surface density of immobilized phage is desirable to increase sensitivity. Since more than $95 \%$ of the phages isolated to date are tailed [22], and thus asymmetric in terms of the placement of their capture proteins, it is crucial that an immobilized phage be oriented on the surface in a manner that leaves its capture proteins exposed to the host. In this paper, we review the current state of knowledge in designing bioactive surfaces with immobilized phage and offer a critical perspective of the challenges in this field.

\section{PHAGE IMMOBILIZATION}

\subsection{Physisorption, electrostatic attachment and covalent bonding}

Numerous approaches have been reported in the literature to effectively immobilize phage on a substrate. These immobilization methods are summarized with respect to bacterial biosensing, bacterial capture and antimicrobial activity in Tables 1, 2 and 3, respectively. These tables present quantitative data on effectivity in terms of detection limits, bacterial capture per unit area and antimicrobial effect, respectively. Most of these approaches involve physisorption [7, 42-67]. This is a very simple approach, but the physisorbed phage can detach from the substrate due to shear or changes in temperature, $\mathrm{pH}$ or ionic strength of the medium which is particularly troublesome for 
biosensing applications. Since most virions have an overall negative charge at neutral $\mathrm{pH}$ [68], several researchers have used electrostatic binding to immobilize phage $[68,69]$. This approach also suffers from instability and phage detachment in response to changes in physico-chemical properties of the medium. Covalent attachment of phage offers a much stronger bond and is not susceptible to easy phage detachment [70-82]. By targeting endogenous amino acids on the protein envelope of the virus, such as lysines, glutamic or aspartic acids, cysteines or (less common) phenol ring of tyrosines, many of the basic protein conjugation schemes can be used to attach phage to substrates of choice (Figure 2) [83, 84]. Appropriate chemistries can be tailored to the selected substrate and target application. Covalent binding results in a higher phage surface density, which is particularly desirable for biosensor applications [85-89]. Singh et al. report a 37fold improvement of bacteriophage attachment with covalently bound phage when compared with physisorption (Table 2) [82]. Although covalent binding is able to provide a more stable immobilized phage layer, Klem et al. have shown that tightly bound, viral cages did not allow for lateral mobility of the virus layer and ultimately hampered the formation of a tightly packed virus layer [90]. This could be of interest for biotemplate design applications. Furthermore, covalent binding is not by itself able to orient phage. The derivatized virions will bind to the substrate in an uncontrolled orientation resulting from their random diffusion to the surface. This would have direct implications for the bioactive performance of a phage modified surface. Phage orientation will be discussed in detail in section 3 .

It is important to bear in mind that some chemistries have the potential to damage phage integrity and/or decrease phage infectivity due to harsh reaction conditions (e.g., $\mathrm{pH}$, solvents, temperature) or over derivatization of phage capture proteins, as reported by Sun et al. [91]. For designing bioactive surfaces, it is important that the phage remains infective or at least able to capture the 
host; therefore, chemistries should be tested and optimized to minimize their effect on phage integrity. Moreover, many chemistries render the substrate single-use, requiring harsh cleaning steps for regeneration which may destroy the biosensing platform; this should also be kept in mind for applications where cost is a limiting factor.

\subsection{Genetic modification and phage-display}

Phage-display technology is a powerful tool that enables peptides of choice to be displayed on the phage envelope. Phages expressing a certain peptide can subsequently be immobilized on a surface if the surface is coated with a ligand specific to that peptide. Phage display libraries (landscape phage libraries) are created by inserting randomized DNA fragments into individual phages so that each phage displays a unique peptide expressed by the inserted DNA fragment [92]. Phage display technology emerged as a synergy of two fundamental concepts, combinatorial peptide libraries and fusion phage [93]. The first concept employs libraries of various peptides obtained in parallel synthesis as opposed to synthesis of individual peptides [94]; the second allows displaying foreign peptides on the surface of bacteriophages [93]. The merge of these two concepts resulted in development of phage display libraries, multibillion clone compositions of self-amplified and selfassembled biological particles [80].

The most common bacteriophages used in phage display are M13, $\mathrm{fd}$ and $\mathrm{f} 1$ filamentous phage, although other phages (filamentous and non-filamentous) have also been used [95]. Filamentous phage are thread-shaped, flexible viruses (Figure 1), whose cylindrical shell consists of the major coat protein $\mathrm{p} 8$. The poles of the phage are capped by five $\mathrm{p} 3$ and $\mathrm{p} 6$ subunits on one end (bacterial capture proteins), and by five p7 and $\mathrm{p} 9$ subunits at the other end [30]. Among the sequences for the major and minor coat proteins, those for $\mathrm{p} 3, \mathrm{p} 8$, and $\mathrm{p} 9$ are particularly amenable for genetic 
modification; therefore, up to three different types of peptides can be expressed on the surface of a filamentous phage resulting in a multifunctional virion [96]. These functional virions are not limited to detecting their host bacteria and can be immobilized on a surface using one peptide while the other peptide(s) are used to capture cells/analytes of choice [72]. This display "machinery" is ideally suited to the production of artificial receptors competitive with antibodies in terms of the strength and specificity of the molecular recognition interaction, but which can be produced in considerable quantities easily and rapidly [97].

It is noteworthy that genetic modification can change the properties of the modified phage. For example, Tolba et al. fused the biotin carboxyl carrier protein gene (bccp) or the cellulose binding module gene $(\mathrm{cbm})$ with the small outer capsid protein gene (soc) of phage T4 (tailed phage) which affected phage infectivity, resulting in a significantly reduced burst size as well as a prolonged latent period [98].

\subsection{Entrapment in porous matrices}

Immobilization within a semi-solid micro-porous matrix allows to structurally and functionally stabilize the phage particles, retaining their activity for extended periods of time. The immobilization of phage by entrapment within a porous matrix (e.g., hydrogels, (bio)polymeric matrices of alginate and agar) is the method of choice for applications where the virions must be

protected against harsh conditions [99-101]. Furthermore, entrapment could serve to retain humidity, which is critical for the infectivity of many phages, or protect the virions in lyophilized form $[102,103]$. A successful commercial example of phage entrapment is PhagoBioDerm [8, 104, 105], a 0.2-mm thick, perforated polymeric wound dressing impregnated with a mixture of lytic bacteriophages and other biocides [106]. 
The matrix used for phage entrapment could hinder contact of the immobilized phage particles with host cells/analytes in the surrounding medium [59], thus decreasing the efficiency of the bioactive surface. To address this concern, employing controlled release entrapment platforms is of particular advantage. Such systems could be used to design wound dressings, antimicrobial coatings or food packagings that release phage in a time-dependent manner [107]. Electrospinning phage into polymer nanofibers has been performed by some researchers to design such controlled release platforms [107-109]. When designing controlled release encapsulation systems, care must be exercised to not compromise phage stability [110], its lytic ability [101] or its interaction with its target host/analyte $[111,112]$ by the employed chemicals/polymers. Furthermore, some phages possess enzymes that degrade certain natural polymers (e.g., alginate [113]) which complicates the use of these polymers as the main component of a protective porous matrix [114].

\subsection{Layer by layer assembly}

Some researchers have explored the possibility to immobilize viruses by alternate layering with oppositely charged polyelectrolytes, claiming to observe improved virus particle surface coverage [115-120]. Yoo et al. have described a layer by layer approach where filamentous M13 phage, embedded between layers of oppositely charged weak polyelectrolytes, was able to diffuse to the top layer and spontaneously form a close packed phage monolayer [119]. The same group has demonstrated that the key aspect for spontaneous formation of densely packed and highly ordered self assembly of filamentous M13 phage on polymer surfaces is the molecular mobility of the polymer [120]. Spontaneous assembly into a densely packed monolayer was only possible with polymers of high molecular mobility, allowing for lateral mobility of the deposited phage.

\subsection{Infectivity of immobilized phage}


As mentioned above, irrespective of the method of immobilization, it is crucial that the immobilized phage retains its infectivity. Although bacteriophages are much more robust than other commonly used biorecognition elements (e.g., antibodies, enzymes etc.), they could be inactivated by harsh conditions (chemicals, $\mathrm{pH}$, etc.). Phages are specifically sensitive to moisture and can be deactivated when dried. Some phages are re-activated upon re-wetting whereas others are permanently inactivated $[68,121,122]$. Nonetheless, the addition of polysaccharides such as $0.5 \%$ maltose or $0.3 \%$ starch was reported to significantly enhance the tolerance of T4 phage to the air-drying effect [68]. Lyophilization has also been reported as an effective approach to store and protect phage when used with appropriate chemical protectants [68]. There are few reports on the stability of immobilized phage in various environmental conditions $(\mathrm{pH}$, salt, temperature, organic chemicals and macromolecules) for immobilization platforms other than entrapment matrices; available information is summarized in Table 4. A notable finding by Dixon et al. was that environmental and clinical interferents can affect the efficiency of phage-functionalized bioactive surfaces even if infectivity of free phage is not affected [123]. This highlights the need for phage-functionalized substrates to be tested under conditions relevant to the final application.

\subsection{Effect of physico-chemical conditions on phage immobilization}

The assembly of molecules and particles is directed by van der Waals, electrostatic and/or hydrophobic interactions. Changing the physico-chemical properties of the medium or the surface chemistry of the substrate or the virion is thus expected to change the balance of these forces and affect the density and arrangement of virions on the substrate [124]. Aggregation/flocculation of virions under certain physico-chemical conditions in suspension is a well documented phenomenon and is a direct consequence of a shift in the balance of these forces [125]. By 
controlling the physic-chemical conditions of the medium, it is possible to achieve a high surface coverage of phage without forming patches of phage aggregates.

The main body of literature dealing with the effect of physico-chemical conditions of the medium on phage-surface interactions can be divided into two main categories; namely, surface interactions of filamentous phage (of interest due to various applications of landscape phage) and surface interactions of icosahedral phages MS2 and PRD1 (of interest due to the use of these phages as surrogates for human viruses in evaluation of water treatment systems). Most of the literature in the latter case investigates the attachment/detachment of viruses to porous matrices (bare or coated sand) [125-132] and does not provide much insight into virus assembly on the substrate. Many of the observed effects, however, are fundamental and equally valid for non-porous substrates and can serve as a valuable guideline for designing bioactive surfaces [133]. Amongst the few in-depth studies on assembly of isosahedral phage on non-porous substrates, Archer and Liu investigated the organization of physisorbed T4 virions (genetically modified to omit the tail) on mica at a range of $\mathrm{pHs}$ and salt concentrations [134]. They reported that the virions are prone to aggregation on the surface under high ionic strength or low $\mathrm{pH}$. Furthermore, changing the substrate or coating the virions with poly(ethylene glycol) significantly affected phage assembly and aggregation on the substrate [134].

It is noteworthy that due to interest in templating applications, surface interaction and assembly of plant viruses have been the subject of several in-depth studies [135-138]. Reports on cowpea mosaic virus indicate that $\mathrm{pHs}$ close to the isoelectric point of the virion result in the best surface coverage by reducing the electrostatic repulsion between the virions, but allowing for electrostatic attraction between the phage and the substrate [115]. This report, as well as many 
other studies on plant viruses can be valuable in designing phage-functionalized bioactive surfaces; however, differences in shape, size and surface chemistry must be taken into account. The versatility of landscape phage is the main driving force behind research on surface interactions of filamentous bacteriophage. Filamentous phage are prone to lateral aggregation or bundling [139] which results in fewer exposed binding sites. Based on polyelectrolyte theory, low salt concentration reduces the phage's axial charge density and thereby promotes bundling and vice versa [140]. However, DLVO theory predicts that low salt concentrations increase electrical double layer repulsion and thus decrease bundling [141]. In practice, filamentous phage physisorbed on gold exhibit minimal phage bundling at intermediate salt concentration (140-840 $\mathrm{mM}$ ) [42, 142]. Furthermore, addition of salts of different nature has been shown to augment hydrophobic associations between virus particles and hydrophobic membranes [143]. This effect is more pronounced for antichaotropic salts [144].

\subsection{Quantifying phage surface density}

Quantification of phage surface density or surface coverage is important in designing bioactive surfaces, particularly for biosensor applications where the surface density of the virions is believed to significantly impact the sensitivity of the device. Direct methods such as scanning electron microscopy (SEM) [145, 146], atomic force microscopy (AFM) [70] and evanescent wave light scattering [147] have been employed for this purpose. Although these methods are reliable because they involve direct observation of the immobilized phage on the substrate, they are labour intensive and, if not performed correctly, are subject to significant bias. Amongst these, evanescent wave light scattering offers the possibility to quantify the deposition of phage on the substrate in realtime [147]. Indirect methods can be employed to deduce the surface coverage or the mass of phage deposited on a substrate. Platforms such as opto-fluidic ring resonators [148], quartz crystal 
microbalances (QCM) [71, 115] and surface plasmon resonance (SPR) [149] have been employed to approximate the mass of virus attached to the substrate. Molecular analysis methods such as $\mathrm{x}-$ ray photoelectron spectroscopy (XPS) or Fourier transform infrared reflection (FTIR) spectroscopy could also provide an indirect measurement by quantifying certain functional groups

(e.g., amine or carboxyl) [146]. There is no comparison reported in the literature between direct and indirect methods to serve as a guideline for crediting the indirect methods and thus care must be taken to observe the bias and the limitations of each method.

\subsection{Efficiency of biosensing platforms with immobilized phage}

The efficiency of biosensing platforms are most often measured by the lowest concentration of bacteria/analyte that they can detect. This has led researchers to strive to increase the phage surface coverage to push the limits of detection. It is important to note that based on Table 1, the detection limit did not change significantly for sensors that immobilized phage by covalent bonding, compared to the platforms that immobilized phage by physisorption. This suggests that, although an important factor, phage surface coverage is not necessarily the bottleneck for improving the sensitivity of a phage-based biosensor. The biosensors presented in Table 1 are based on different transduction platforms and the limit of detection can vary depending on the operational principle of the transduction platform. Tawil et al. suggested that for SPR biosensors, due to the limited penetration depth of the surface plasmon evanescent field $(300 \mathrm{~nm})$, the use of smaller phage allows for a larger portion of the captured bacteria to be probed by the biosensor and thus yields a larger SPR response [150]. Although the authors did not explore whether using smaller phage would improve the lower detection limit, they shed light on a very important design factor that deserves to be investigated further. 
The characteristic transduction signal for a QCM platform is the change in frequency and/or dissipation of the oscillations of the quartz crystal induced by mass deposited on the crystal. This change in frequency and dissipation is governed by the nature of the coupling between the deposited mass and the sensor surface [151]. If a flexible bond is formed, the frequency will increase (positive shift), and if a rigid bond is formed, the frequency will decrease (negative shift) [152]. Bacteria captured by a filamentous phage immobilized on a QCM crystal have been reported to give rise to a positive frequency shift [61]. This can be explained by a coupled resonance model where the magnitude of the QCM response (negative or positive) depends on how close the inherent resonance frequency of the attached particle (determined by its mass $m$ and bond stiffness $k$ ) is to the inherent resonance frequency of the quartz crystal [153-155]. Therefore, the QCM response per individual captured bacterium, and thus the sensitivity of the sensor, depends on the nature of the contact between surface and the bacteria. This will in turn depend on the type of phage (shape, interaction with host, surface hydrophobicity, etc.), phage orientation on the surface, phage surface density and on the nature of the bond between the phage and the sensor surface. In other words, the choice of phage can be crucial for the performance of the sensor. Thus, it is not surprising that Guntupali et al. were able to significantly alter the QCM response for bacterial capture by chloroform treatment of the immobilized phage which resulted in a contracted, yet fully functional phage with a short, thick and non-flexible tail [156].

Another important observation reported in the literature is that bacterial capture efficiency increased with increasing phage surface coverage only up to a threshold surface density, after which it decreased dramatically [157]. It was suggested that above the optimal phage surface density, the virions are too close to each other which invokes entanglement of their tail fibers, preventing their interaction with host bacteria. It could also be hypothesized that electrostatic 
repulsion between the virions hinders the increase of phage surface density above a certain threshold. It is noteworthy that covering a substrate with phage changes its physico-chemical properties and could give rise to hydrophobic, electrostatic, and even steric interactions with bacteria and subsequently decrease bacterial capture. This fact is highlighted by Dixon et al. who showed that the bacteria capture efficiency of a surface functionalized with a hydrophobic phage was different from that functionalized with a hydrophilic phage [123]. Evoy and coworkers also reported very different host capture efficiencies with three tailed phages covalently immobilized on gold [157]. Only one E. coli cell was captured per 1887 immobilized T4 virions, this number changed to 1 Salmonella cell per 41 P22 virions and 1 Campylobacter cell per three phage (NCTC 12673). Taking into account the high affinity of T4 phage for its host, this large difference in host capture could be partially explained by the different physico-chemical properties of the immobilized phage layer.

Finally, it is worth noting that not all phages remain attached to their host after infection. This can result in decreased sensitivity and bias for biosensors. This problem can be circumvented by choosing the right phage. Also, if infection of the bacteria is not desirable for the sensing platform, ghost phage (phage without genome [158]) could be constructed to take advantage of the specific interaction of phage with its host without the complication of phage infection.

\section{ORIENTATION OF IMMOBILIZED PHAGE}

Once immobilized on the surface of interest, phage efficiency in capturing its host often decreases. This can be attributed to the fact that the majority of phages are of bilateral geometry, consisting of a capsid encapsulating the phage genome and a tail through which they bind to and inject their genome into their host. The immobilized phage will only be able to retain its activity on the surface 
if it is oriented in such a way that its binding receptors are exposed and able to interact with receptors on the host bacterium (Figure 3). This is reminiscent of similar limitations with the wellknown specific recognition element, the antibody. Like most phages, antibodies are highly asymmetric; improvement factors as high as 200 have been reported by controlling their surface orientation [159].

The importance of orientation of immobilized phage is exemplified in our earlier work [146]; phages with different shapes and symmetries were selected against the same host and covalently immobilized on a substrate. Substrates functionalized with tailed phages exhibited lower bacterial capture efficiency compared to symmetric icosahedral phages. It was postulated that the cause for a lower capture efficiency of asymmetric phages was their mixed orientation on the surface which leaves the bacterial capture proteins on their tail fibers unexposed and thus unable to interact with host receptors. Interestingly, asymmetric phages that could bind to bacterial pili had relatively higher capture efficiencies as compared to asymmetric phages that bind to bacterial surface proteins, possibly due to the higher availability of the pili to reach phage capture proteins for unfavorably oriented virions [146]. This finding demonstrates that the location of phage binding sites on the bacterial cell is an important aspect to consider for the bioactivity of the phagefunctionalized surface.

It should be noted that the desired orientation of the immobilized phage depends on the intended application of the bioactive surface. For antimicrobial surfaces and biosensors designed to utilize the inherent binding specificity and lytic activity of phage towards the bacterial host, tailed phage should be orientated with their tail directed away from the surface and filamentous phage with their bacterial-capturing pole exposed (Figure 3) [42]. For filamentous landscape phage with peptides expressed on their cylindrical envelope, it is desirable for the virions to align more or less 
parallel to each other on the surface which ensures the exposure of peptides to capture the analyte(s). In the following, potential strategies are presented for orienting phage virions.

\subsection{Electrostatic orientation}

The electrophoretic mobility of the negatively charged T7 phage has been reported to increase when its tail fibers are detached, suggesting a slight positive charge for the tail fibers [160]. Anany et al. also reported that while charge of intact T4 phage was negative, the charge of tail and tail fibers alone were slightly positive [68]. Researchers have demonstrated that this inherent charge difference can be exploited to orient a tailed phage on a positively charged [69] or positively

polarized substrate [161] (Figure 4a). Tunneling electron micrographs suggested that tailed phages preferably adhered "head-down" to a positively charged aminosilane-modified silica microsphere [69]. Although not demonstrated for phage, cyclic voltammetry has been successfully employed to orient antibodies on gold substrates [162].

Tuning the electrostatic repulsion between the virions is another potential way to orient phage. Peng et al. demonstrated this concept for the rod-shaped tobacco mosaic virus (TMV) [163]; by increasing the $\mathrm{pH}$ above the isoelectric point of the virion (3.4), they managed to change the orientation of the viruses (Figure 4b). At lower $\mathrm{pH}$, the rods carried less negative charges, thus their assembly on the gold substrate was relatively slow, and the particles vertically attached to the substrate. At high $\mathrm{pH}$, and thus higher virion negative charge, attachment kinetics was much faster, and the rod-like particles deposited horizontally on the gold surface [163]. Changing the $\mathrm{pH}$ also affects the charge and hydrophobicity of the gold substrate [164] which could also contribute to the resulting phage orientation.

\subsection{Genetic modification}


Genetic modification is likely the most effective way to orient phage. Landscape phage with peptides that can specifically bind to certain substrates are a perfect example of this case. However, there are complications that can arise. Researchers from University of Guelph cloned biotin carboxyl carrier protein gene $(b c c p)$ or the cellulose binding module gene $(\mathrm{cbm})$ into T4 phage [98]. The biotin-binding phage performed well when immobilized on biotin-coated beads [145]; the cellulose-binding phage, however, failed to capture bacteria when immobilized on cellulose [98]. It was concluded that despite the availability of cellulose affinity tags on the phage head, there was still a possibility for phage tails to interact with sugar moieties on the surface of microcrystalline cellulose [98]. This interaction is similar to the interaction with polysaccharides on the surface of the bacterial cell. Thus, the affinity of the tail fibers to attach to polysaccharides (cellulose substrate) apparently overcame the affinity of the CBM proteins on the phage capsid.

\subsection{Molecular imprinting}

Molecular imprinting has become an increasingly popular method for the design of artificial antibodies against a variety of analytes [165]. The technique involves using a template analyte to pattern a deformable polymer. The patterned layer is then used for the recognition of an analyte that is a geometrical fit with the template (Figure 4c). This method was successfully used to detect viruses [166]. An alternative technique to prepare the patterned layer is to polymerize a monomer directly around a template analyte [167] (Figure 4d). Although not demonstrated for this purpose, molecular imprinting has the potential to be used for orienting tailed phage by using an icosahedral phage or virus as template.

Tawil et al. claim to have inadvertently used a similar approach to orient phage [76]. They reported that phage immobilized on gold coated with L-cysteine conjugated to 11-mercaptoundecanoic acid 
was very efficient in infecting a population of host bacteria. AFM investigation revealed cavities on this surface that were of similar diameter and depth as the phage capsid leading the authors to hypothesize that surface topography had forced the phage capsid into the cavities thus orienting the phage. Since the authors did not quantify phage surface densities or bacterial capture for the phage-functionalized surfaces, it is difficult to conclude whether the higher infectivity was due to higher phage density or favorable phage orientation.

\subsection{Assembly at liquid-liquid interface}

The use of liquid interfaces as platforms to assemble inorganic nanoparticles has garnered considerable attention. Self-assembly at organic-aqueous interfaces is driven by reduction in interfacial energies and, thereby, in Gibbs free energy, making it thermodynamically favorable [168]. Although this approach has yet to be tested for phage, it was successfully demonstrated for orienting the rod-shaped tobacco mosaic virus (TMV) at the perfluorodecalin/water interface (Figure 4e). At low virus concentration, the TMV particles organized themselves parallel to the interface but as the concentration increased, they oriented themselves perpendicular to the interface to accommodate the increased packing density and also neutralize inter-rod electrostatic repulsion [169].

\subsection{Assembly at liquid-air interface}

In 1917, Langmuir demonstrated that long-chain fatty acids form, on water, films that are one molecule thick and that the molecules are oriented on the water surface with the polar functional group immersed in the water and the long nonpolar chain directed nearly vertically away from the surface [170]. This technique enables high quality organic layers (Langmuir-Blodgett films) to be deposited onto a variety of substrates [171]. Guntupalli et al. have explored this approach to control 
the orientation of phage by forming a Langmuir-Blodgett film at an air-liquid interface [172]. They found that phages in a Langmuir-Blodgett film gradually change their orientation from horizontal, to oblique, to vertical as the bulk phage concentration (and thus pressure) increases (Figure $4 \mathbf{f}$ ). Once formed, the Langmuir-Blodgett film could be transferred to the solid-liquid interface simply by dipping the substrate into the solution where the film was formed, as verified by ellipsometry and SEM. Although the orientation was somewhat compromised, forming phage LangmuirBlodgett films proved to be an interesting self-assembly approach to control the orientation of phage. The authors further used this technique to immobilize a layer of tailed phage on gold QCM crystals for biosensing application (Table 1) [156].

A simple technique to assemble phage at the air-liquid interface was demonstrated for orienting filamentous phage [173]. A landscape phage expressing a polymer-binding peptide on one pole was employed. When the substrate was dipped into the phage suspension the filaments attached to the substrate from one end. When the substrate was pulled out of the liquid, the shear imposed on the phage filaments resulted in the coiled filaments to stretch out and deposit parallel to each other (Figure 4g). The same result can be achieved by drying a drop of a phage suspension on a surface while simultaneously tilting the surface and blowing air over the drop in a fixed direction (Figure 4h) [174]. Stretching the filaments was shown to be successful as long as the phage were attached to the surface via one pole with an intermediate bond strength (i.e. weak enough to unfold, but strong enough to resist to shear). This technique, first used to immobilize and align DNA strands, which is strongly dependent on the $\mathrm{pH}$ of the phage suspension [175], has the potential to be employed in reducing filamentous phage bundling on biosensor platforms, thereby improving the sensitivity of biosensors exploiting filamentous phage. 
Convective assembly is another method where particles are aligned by capillary forces induced by a slowly receding meniscus formed at the air-liquid-solid interface (Figure 4i). The difference between this technique and the methods described above is that the alignment of the deposited particles and the assembly process are both driven by the capillary forces at the liquid evaporation front [176]. Convective assembly has been described for rod-shaped TMV [177-179] and filamentous phage [180] and the aligned phage have successfully been used to direct the growth of mammalian cells $[178,180]$.

\subsection{Micro contact printing}

Micro contact printing has proven to be a useful technique to pattern self-assembled monolayers on surfaces [181]. Although originally used to pattern molecules [182], it has been demonstrated to work for phages [183] and plant viruses [184]. High local densities of phage are delivered to the surface using a silicone elastomer polydimethylsiloxane (PDMS) stamp patterned via soft lithography (Figure 4j). The method involves adsorbing a monolayer of phage to the hydrophilic surface of the stamp by embedding a small drop between the stamp and a plasma-cleaned glass cover slip. When the cover slip is removed, the virions can potentially be oriented in a manner similar to the orientation in Langmuir-Blodgett films. This ordered phage layer is then stamped on the substrate of choice. Although experiments with TMV have shown that under controlled conditions the nanorods can be aligned [184], it remains to be determined whether this hypothesis can in fact result in an oriented layer of filamentous and tailed phage.

\subsection{Specific binding proteins}

Proteins/peptides that have specific affinity for certain proteins on the phage virion could be coated on a surface and used to orient the phage. This concept has proven very successful for antibody 
orientation. Proteins $\mathrm{G}$ and A display binding domains specific to the $\mathrm{Fc}$ portion of IgG antibodies. Coating a surface with these proteins results in a predominantly tail-on orientation [185]. Factors that affect the conformation of the chosen proteins (e.g., $\mathrm{pH}$ and temperature) can affect the subsequent orientation of the phage or antibody on the surface [186]. Controlling the lateral spacing of the capture protein could also improve the performance of on-chip assays [187].

\subsection{Characterizing phage orientation}

Characterizing the orientation of phage on a surface is of fundamental interest. Immobilized phage can adopt various orientations based on their shape (Figure 3). For the highest bacteria/analyte binding, immobilized phage must be oriented in a manner allowing their binding proteins to interact with the host/analyte. Although there have been claims regarding the use of electron microscopy (SEM, TEM) for characterizing phage orientation [98], these claims should be interpreted with caution since electron microscopy (in most cases) requires drying of the sample which can potentially alter phage orientation. When possible, embedding the phage-functionalized substrate in epoxy resin and preparing microtomes could somewhat circumvent artifacts introduced by drying.

In atomic force microscopy (AFM), surfaces are scanned by a nano-scale tip, resulting in a topographical surface map of soft biomaterials such as proteins and antibodies. From this information, local properties of the surface such as the degree of coverage and the thickness of the layer can be determined. AFM has been used in many instances to measure the height of an antibody layer immobilized on a substrate to distinguish between tail-on and side-on orientation [188-192]. The same method could be applied to phage virions (Figure 5a). To avoid artifacts due to drying of the sample, both the surface and the probe may be immersed in a liquid of choice under a relevant and controllable temperature [193]. A layer of physisorbed phage, however, may 
detach or even change its orientation due to interaction with the AFM tip. Cryo-AFM offers the advantage of slowing the kinetics of surface interactions by drastically lowering the scanning temperature. It should be noted that even in non-contact mode, AFM tip convolution will still induce discrepancies [73].

Using a QCM platform that allows the measurement of dissipation of the oscillations of the quartz crystal (QCM-D), has been shown to provide information required to calculate the size of deposited particles [194]. This method can, in theory, be used to determine the orientation of a layer of adsorbed phage since different orientations will result in adsorbed layers of different thickness (Figure 5b). Researchers have also suggested that the ratio between the two QCM-D output parameters (frequency and dissipation) is indicative of the orientation of filamentous phage $[195,196]$ and TMV [163].

Several other methods have been proposed in the literature for characterizing the orientation of antibodies and/or phage by measuring the thickness of the attached layer. Spectroscopic ellipsometry analyzes the state of polarized light reflected from multilayer reflective samples. The layer thickness can be deduced by model-based analysis (Figure 5c). It should be noted, however, that these models assume continuous thin films and applying them to discrete particles is not free of error. Ellipsometry has been used to deduce information regarding phage orientation by measuring the thickness of the adsorbed layer [172]. Surface Plasmon Resonance (SPR) has been established as a powerful method to monitor label-free biomolecular interactions in liquids (Figure 5d) [197]. SPR platforms have also been used to deduce the thickness and orientation of adsorbed layers of antibodies [198] and phage [57]. Neutron reflectometry is a neutron diffraction technique used to determine the thickness and composition of molecular layers on surfaces with a sensitivity of 2-3 $\AA$ (Figure 5d) [199]. The technique involves directing a beam of neutrons onto a flat 
surface, and measurement of the intensity of the reflected radiation. This method has been demonstrated for characterizing the orientation of antibodies [199-201]. Dual Polarization Interferometry (DPI), an optical wave-guide-based analytical technique, can be used to obtain information on molecular dimensions (layer thickness), packing (layer refractive index, density) and stoichiometry (mass) [202] (Figure 5e). The measured layer thickness has been employed to provide information on the arrangement of antibodies on surfaces [203].

Evanescent wave light scattering and interferometric scattering microscopy (iSCAT) [204] are methods that have great potential to be used for real-time monitoring of phage orientation on a substrate, both providing quantitative and visual information. Evanescent wave light scattering is the principal behind total internal reflection microscopy (TIRM and TIRFM) with which changes in a very thin $(\sim 200 \mathrm{~nm})$ region of specimen can be monitored [205]. Changes in phage orientation within the evanescent light field can alter the intensity of the phage scattered light and thus allow real time monitoring of an absorbed phage layer (Figure 5e). iSCAT is a novel technique that is capable of imaging very small labels at very high speeds. This method has been demonstrated to yield real-time visual information regarding both position and orientation of single quantum dotlabeled virus particles (Figure 5f) and is claimed to provide a higher resolution compared to evanescent wave light scattering [206]. Finally, high-resolution time-of-flight secondary ion mass spectrometry (ToF-SIMS) is a powerful method to obtain biophysical information about the molecular structure of the surface. This technique involves bombardment of a surface with a pulsed primary ion beam that has a sampling depth of $1-3 \mathrm{~nm}$ [207]. The resulting positively or negatively charged ions are analyzed by a time-of-flight mass analyzer, yielding a fingerprint of the attached species (Figure 5f). Since the sampling depth is very shallow, these data can be used to interpret the orientation of immobilized antibodies (and possibly phage) [208-211]. 


\section{CHALlengeS}

The main challenge in designing efficient biosensors based on immobilized phage appears to be controlling the orientation of the immobilized phage. Controlling phage orientation is complicated by the lack of a well-developed method for in situ monitoring of phage orientation. We have identified a number of methods to monitor the orientation of the phage layer. Many of these characterization methods, however, have not been developed for viruses and therefore method development is an area that deserves more attention.

A major challenge in this field is moving beyond laboratory scale, proof of concept experiments and developing bioactive surfaces that can find application in real life. In this regard, it is crucial to understand the effect of environmental interferents on immobilized phage. Proteins and cells in the blood, or macromolecules and colloids in untreated waters can interfere with the efficiency of a biosensor or the performance of an antimicrobial surface. This is a relatively unexplored area in this field since most published research report experiments performed under idealized laboratory conditions. Preliminary results indicate the importance of the choice of phage; phages must be chosen that are not affected by the interferents in the environment in which they are expected to perform. Large scale production of high purity phage is another important step towards real life application of phage-functionalized platforms. The purity of phage can affect both biosensor applications and the safety of phage-based antimicrobial surfaces.

The development of controlled release entrapment platforms is a very promising area for real-life application of phage-based antimicrobial surfaces. Such platforms can find applications in food packaging, wound dressings and even antimicrobial coatings. Entrapment platforms can protect 
the phage against harsh environmental conditions and drying and allow for more versatile antimicrobial surfaces. An important hurdle in realization of phage-functionalized antimicrobial surfaces, which involve long term release of phage in a fixed medium, is concern regarding the development of phage resistance in the target host community. Phage resistance is inevitable and the phage-resistant host population has been reported to be diversified into various phenotypes [212] some of which could even exhibit altered levels of virulence [213, 214]. However, it is possible to choose a phage or a phage mixture that renders the phage-resistant mutants weaker and less virulent. In conclusion, phage-based bioactive surfaces have immense potential for applications in biosensors and antimicrobial surfaces but their realization relies on choosing the right phage(s) for a certain application to overcome inherent limitations and avoid future complications. 


\section{ACKNOWLEDGMENTS}

A.L.J.O. and Z.H. contributed equally to this work. This work was supported by the Natural

Sciences and Engineering Research Council of Canada (NSERC) strategic network for bioactive paper (SENTINEL) and the Canada Research Chairs (CRC) program. 


\section{References}

[1] X. Wang, S. Zhan, Z. Huang and X. Hong, Review: Advances and applications of surface plasmon resonance biosensing instrumentation, Instrumentation Science and Technology, 41 (2013) 574-607.

[2] A. Tuantranont, A. Wisitsora-at, P. Sritongkham and K. Jaruwongrungsee, A review of monolithic multichannel quartz crystal microbalance: A review, Analytica Chimica Acta, 687 (2011) 114-128.

[3] A.M. Foudeh, T. Fatanat Didar, T. Veres and M. Tabrizian, Microfluidic designs and techniques using lab-on-a-chip devices for pathogen detection for point-of-care diagnostics, Lab on a Chip -

Miniaturisation for Chemistry and Biology, 12 (2012) 3249-3266.

[4] S.M.Z. Hossain, C. Ozimok, C. Sicard, S.D. Aguirre, M.M. Ali, Y. Li and J.D. Brennan, Multiplexed paper test strip for quantitative bacterial detection, Analytical and Bioanalytical Chemistry, 403 (2012) $1567-1576$.

[5] C. Sicard and J.D. Brennan, Bioactive paper: Biomolecule immobilization methods and applications in environmental monitoring, MRS Bull., 38 (2013) 331-334.

[6] J.R. Brigati and V.A. Petrenko, Thermostability of landscape phage probes, Anal. Bioanal. Chem., 382 (2005) 1346-1350.

[7] J.J. Curtin and R.M. Donlan, Using bacteriophages to reduce formation of catheter-associated biofilms by Staphylococcus epidermidis, Antimicrob. Agents Chemother., 50 (2006) 1268-1275.

[8] D. Jikia, N. Chkhaidze, E. Imedashvili, I. Mgaloblishvili, G. Tsitlanadze, R. Katsarava, J.G. Morris Jr and A. Sulakvelidze, The use of a novel biodegradable preparation capable of the sustained release of bacteriophages and ciprofloxacin, in the complex treatment of multidrug-resistant Staphylococcus aureusinfected local radiation injuries caused by exposure to Sr90, Clin. Exp. Dermatol., 30 (2005) 23-26.

[9] T.A. Dankovich and D.G. Gray, Bactericidal paper impregnated with silver nanoparticles for pointof-use water treatment, Environ. Sci. Technol., 45 (2011) 1992-1998.

[10] P.A. Tran and T.J. Webster, Antimicrobial selenium nanoparticle coatings on polymeric medical devices, Nanotechnology, 24 (2013).

[11] C.Y. Kim, Y.R. Choi, K.M. Kim and S.Y. Choi, Fabrication and antibacterial properties of silvercoated glass substrate against Escherichia coli, Salmonella typhimurium, Campylobacter jejuni, International Journal of Nanotechnology, 10 (2013) 643-652.

[12] P. Hyman, Bacteriophages and nanostructured materials, in, Vol 78, 2012, pp. 55-73.

[13] M.T. Dedeo, D.T. Finley and M.B. Francis, Viral capsids as self-assembling templates for new materials, in, Vol 103, 2011, pp. 353-392.

[14] K. Gerasopoulos, M. McCarthy, P. Banerjee, X. Fan, J.N. Culver and R. Ghodssi, Biofabrication methods for the patterned assembly and synthesis of viral nanotemplates, Nanotechnology, 21 (2010).

[15] M. Henry and L. Debarbieux, Tools from viruses: Bacteriophage successes and beyond, Virology, 434 (2012) 151-161.

[16] N.F. Steinmetz and M. Manchester, Viral nanoparticles: Tools for materials science and biomedicine, Pan Stanford Publishing Pte. Ltd., 2011.

[17] N. Stephanopoulos and M.B. Francis, Making New Materials from Viral Capsids, in, Vol 9, Elsevier, 2012, pp. 247-266.

[18] S.H. Yang, W.J. Chung, S. McFarland and S.W. Lee, Assembly of bacteriophage into functional materials, Chemical Record, 13 (2013) 43-59.

[19] S.H. Yang, W.-J. Chung, S. McFarland and S.-W. Lee, Assembly of Bacteriophage into Functional Materials, The Chemical Record, 13 (2013) 43-59.

[20] F.W. Twort, An investigation on the nature of ultra-microscopic viruses, Lancet, 2 (1915) 12411243.

[21] F. d'Herelle, An invisible antagonist microbe of dysentery bacillus, C. R. Hebd. Seances Acad. Sci., 165 (1917) 373-375.

[22] S.T. Abedon, Phage Evolution and Ecology, in: Advances in Applied Mircobiology, Vol 67, Vol 67, Elsevier Academic Press Inc, San Diego, 2009, pp. 1-45. 
[23] S. O'Flaherty, R.P. Ross, W. Meaney, G.F. Fitzgerald, M.F. Elbreki and A. Coffey, Potential of the Polyvalent Anti-Staphylococcus Bacteriophage K for Control of Antibiotic-Resistant Staphylococci from Hospitals, Appl. Environ. Microbiol., 71 (2005) 1836-1842.

[24] J.E. Blair and R.E.O. Williams, Phage typing of staphylococci, Bull. World Health Organ., 24 (1961) 771-784.

[25] H.W. Ackermann, Classification of bacteriophages, in: R.L. Calendar (Ed.) The Bacteriophages, Oxford University press, New York, 2006.

[26] D.E. Bradley, Ultrastructure of bacteriophage and bacteriocins, Bacteriol. Rev., 31 (1967) 230-314.

[27] E. Kutter and A. Sulakvelidze, Bacteriophages biology and applications, CRC Press, Boca Raton, FL, 2005.

[28] A.M. Grahn, S.J. Butcher, J.K.H. Bamford and D.H. Bamford, PRD1: Dissecting the genome, structure, and entry, in: R.L. Calendar (Ed.) The Bacteriophages, Oxford university press, 2005.

[29] J. Van Duin and N. Tsareva, Single-stranded RNA phages, in: R.L. Calendar (Ed.) The bacteriophages, Oxford University Press, 2005.

[30] B.A. Fane, K.L. Brentlinger, A.D. Burch, M. Chen, S. Hafenstein, D.E. Moore, C.R. Novak and A. Uchiyama, Cubic and filamentous phages, in: R.L. Calendar (Ed.) The bacteriophages, Oxford university press, 2005.

[31] G. Mosig and F. Eiserling, T4 and related phages: Structure and development, in: R.L. Calendar

(Ed.) The bacteriophages, 2005.

[32] J. Rakonjac, N.J. Bennett, J. Spagnuolo, D. Gagic and M. Russel, Filamentous bacteriophage: biology, phage display and nanotechnology applications, Curr. Issues Mol. Biol., 13 (2011) 51-76.

[33] M. Ptashne, A genetic switch : phage lambda revisited, Cold Spring Harbor Laboratory Press, Cold Spring Harbor, N.Y., 2004.

[34] J.W. Little, Lysogeny, prophage induction, and lysogenic conversion. , in: M.K.F.D.I.A.S.L. Waldor (Ed.) Phages : their role in bacterial pathogenesis and biotechnology, ASM Press, Washington, D.C., 2005, pp. 37-65.

[35] T. Steiner, Treating foodborne illness, Infect. Dis. Clin. North Am., 27 (2013) 555-576.

[36] N.N. Schommer and R.L. Gallo, Structure and function of the human skin microbiome, Trends Microbiol., (2013).

[37] O. Bondarenko, K. Juganson, A. Ivask, K. Kasemets, M. Mortimer and A. Kahru, Toxicity of Ag, $\mathrm{CuO}$ and $\mathrm{ZnO}$ nanoparticles to selected environmentally relevant test organisms and mammalian cells in vitro: A critical review, Arch. Toxicol., 87 (2013) 1181-1200.

[38] S. Kalghatgi, C.S. Spina, J.C. Costello, M. Liesa, J.R. Morones-Ramirez, S. Slomovic, A. Molina, O.S. Shirihai and J.J. Collins, Bactericidal antibiotics induce mitochondrial dysfunction and oxidative damage in mammalian cells, Sci. Transl. Med., 5 (2013).

[39] M.T. Horne, Coevolution of Escherichia coli and bacteriophages in chemostat culture, Science, 168 (1970) 992-\&.

[40] A.M. Comeau and H.M. Krisch, War is peace - dispatches from the bacterial and phage killing fields - Commentary, Curr. Opin. Microbiol., 8 (2005) 488-494.

[41] B.R. Levin and J.J. Bull, Population and evolutionary dynamics of phage therapy, Nature Reviews Microbiology, 2 (2004) 166-173.

[42] S. Huang, H. Yang, R.S. Lakshmanan, M.L. Johnson, I. Chen, J. Wan, H.C. Wikle, V.A. Petrenko, J.M. Barbaree, Z.Y. Cheng and B.A. Chin, The effect of salt and phage concentrations on the binding sensitivity of magnetoelastic biosensors for Bacillus anthracis detection, Biotechnol. Bioeng., 101 (2008) 1014-1021.

[43] L. Fu, S. Li, K. Zhang, I.H. Chen, J.M. Barbaree, A. Zhang and Z. Cheng, Detection of Bacillus anthracis spores using phage-immobilized magnetostrictive milli/micro cantilevers, IEEE Sens. J., 11 (2011) 1684-1691.

[44] W. Shen, R.S. Lakshmanan, L.C. Mathison, V.A. Petrenko and B.A. Chin, Phage coated magnetoelastic micro-biosensors for real-time detection of Bacillus anthracis spores, Sensors and Actuators, B: Chemical, 137 (2009) 501-506. 
[45] R.S. Lakshmanan, R. Guntupalli, J. Hu, D.-J. Kim, V.A. Petrenko, J.M. Barbaree and B.A. Chin, Phage immobilized magnetoelastic sensor for the detection of Salmonella typhimurium, J. Microbiol. Methods, 71 (2007) 55-60.

[46] S. Li, Y. Li, H. Chen, S. Horikawa, W. Shen, A. Simonian and B.A. Chin, Direct detection of Salmonella typhimurium on fresh produce using phage-based magnetoelastic biosensors, Biosensors Bioelectron., 26 (2010) 1313-1319.

[47] M.K. Park, K.A. Weerakoon, J.H. Oh and B.A. Chin, The analytical comparison of phage-based magnetoelastic biosensor with TaqMan-based quantitative PCR method to detect Salmonella typhimurium on cantaloupes, Food Control, 33 (2013) 330-336.

[48] M.K. Park, N. Hirematha, K.A. Weerakoon, K.A. Vaglenov, J.M. Barbaree and B.A. Chin, Effects of surface morphologies of fresh produce on the performance of phage-based magnetoelastic biosensors, J. Electrochem. Soc., 160 (2013) B6-B12.

[49] M.K. Park, J.W. Park, H.C. Wikle Iii and B.A. Chin, Evaluation of phage-based magnetoelastic biosensors for direct detection of Salmonella typhimurium on spinach leaves, Sensors and Actuators, B: Chemical, 176 (2013) 1134-1140.

[50] M.K. Park, S. Li and B.A. Chin, Detection of Salmonella typhimurium Grown Directly on Tomato Surface Using Phage-Based Magnetoelastic Biosensors, Food and Bioprocess Technology, 6 (2013) 682689.

[51] M.K. Park, J.H. Oh and B.A. Chin, The effect of incubation temperature on the binding of Salmonella typhimurium to phage-based magnetoelastic biosensors, Sensors and Actuators, B: Chemical, 160 (2011) 1427-1433.

[52] M.K. Park, H.C. Wikle, Y. Chai, S. Horikawa, W. Shen and B.A. Chin, The effect of incubation time for Salmonella typhimurium binding to phage-based magnetoelastic biosensors, Food Control, 26 (2012) 539-545.

[53] W. Shen, S. Li, M.K. Park, Z. Zhang, Z. Cheng, V.A. Petrenko and B.A. China, Blocking agent optimization for nonspecific binding on phage based magnetoelastic biosensors, J. Electrochem. Soc., 159 (2012) B818-B823.

[54] L. Carson, S.P. Gorman and B.F. Gilmore, The use of lytic bacteriophages in the prevention and eradication of biofilms of Proteus mirabilis and Escherichia coli, FEMS Immunol. Med. Microbiol., 59 (2010) 447-455.

[55] W. Fu, T. Forster, O. Mayer, J.J. Curtin, S.M. Lehman and R.M. Donlan, Bacteriophage cocktail for the prevention of biofilm formation by Pseudomonas aeruginosa on catheters in an in vitro model system, Antimicrob. Agents Chemother., 54 (2010) 397-404.

[56] M. Smietana, W.J. Bock, P. Mikulic, A. Ng, R. Chinnappan and M. Zourob, Detection of bacteria using bacteriophages as recognition elements immobilized on long-period fiber gratings, Opt. Express, 19 (2011) 7971-7978.

[57] V. Nanduri, S. Balasubramanian, S. Sista, V.J. Vodyanoy and A.L. Simonian, Highly sensitive phage-based biosensor for the detection of beta-galactosidase, Anal. Chim. Acta, 589 (2007) 166-172. [58] S. Balasubramanian, I.B. Sorokulova, V.J. Vodyanoy and A.L. Simonian, Lytic phage as a specific and selective probe for detection of Staphylococcus aureus - A surface plasmon resonance spectroscopic study, Biosens. Bioelectron., 22 (2007) 948-955.

[59] V.M. Balcão, A.R. Moreira, C.G. Moutinho, M.V. Chaud, M. Tubino and M.M.D.C. Vila, Structural and functional stabilization of phage particles in carbohydrate matrices for bacterial biosensing, Enzyme Microb. Technol., 53 (2013) 55-69.

[60] A.R. Bennett, F.G.C. Davids, S. Vlahodimou, J.G. Banks and R.P. Betts, The use of bacteriophagebased systems for the separation and concentration of Salmonella, J. Appl. Microbiol., 83 (1997) 259265.

[61] E.V. Olsen, I.B. Sorokulova, V.A. Petrenko, I.H. Chen, J.M. Barbaree and V.J. Vodyanoy, Affinityselected filamentous bacteriophage as a probe for acoustic wave biodetectors of Salmonella typhimurium, Biosensors Bioelectron., 21 (2006) 1434-1442. 
[62] R.S. Lakshmanan, R. Guntupalli, J. Hu, V.A. Petrenko, J.M. Barbaree and B.A. Chin, Detection of Salmonella typhimurium in fat free milk using a phage immobilized magnetoelastic sensor, Sens.

Actuator B-Chem., 126 (2007) 544-550.

[63] J. Wan, M.L. Johnson, S. Horikawa, B.A. Chin and V.A. Petrenko, Characterization of phagecoupled magnetoelastic micro-particles for the detection of Bacillus anthracis Sterne spores, in: 6th IEEE Conference on SENSORS, IEEE SENSORS 2007, Atlanta, GA; United States, 2007, pp. 1085-1088.

[64] M.B. Mejri, H. Baccar, E. Baldrich, F.J. Del Campo, S. Helali, T. Ktari, A. Simonian, M. Aouni and A. Abdelghani, Impedance biosensing using phages for bacteria detection: Generation of dual signals as the clue for in-chip assay confirmation, Biosensors Bioelectron., 26 (2010) 1261-1267.

[65] V. Nanduri, A.K. Bhunia, S.I. Tu, G.C. Paoli and J.D. Brewster, SPR biosensor for the detection of L. monocytogenes using phage-displayed antibody, Biosensors Bioelectron., 23 (2007) 248-252.

[66] A. Mazhorova, A. Markov, A. Ng, R. Chinnappan, O. Skorobogata, M. Zourob and M.

Skorobogatiy, Label-free bacteria detection using evanescent mode of a suspended core terahertz fiber, Opt. Express, 20 (2012) 5344-5355.

[67] S. Li, S. Horikawa, M.K. Park, Y. Chai, V.J. Vodyanoy and B.A. Chin, Amorphous metallic glass biosensors, Intermetallics, 30 (2012) 80-85.

[68] H. Anany, W. Chen, R. Pelton and M.W. Griffiths, Biocontrol of listeria monocytogenes and e. Coli o157:H7 in meat using phage immobilized on modified cellulose membranes, Appl. Environ. Microbiol., (2011) AEM.05493-05411.

[69] R. Cademartiri, H. Anany, I. Gross, R. Bhayani, M. Griffiths and M.A. Brook, Immobilization of bacteriophages on modified silica particles, Biomaterials, 31 (2010) 1904-1910.

[70] S. Horikawa, D. Bedi, S. Li, W. Shen, S. Huang, I.H. Chen, Y. Chai, M.L. Auad, M.J. Bozack, J.M. Barbaree, V.A. Petrenko and B.A. Chin, Effects of surface functionalization on the surface phage coverage and the subsequent performance of phage-immobilized magnetoelastic biosensors, Biosensors Bioelectron., 26 (2011) 2361-2367.

[71] L.-M.C. Yang, J.E. Diaz, T.M. McIntire, G.A. Weiss and R.M. Penner, Covalent Virus Layer for Mass-Based Biosensing, Anal. Chem., 80 (2008) 933-943.

[72] L.-M.C. Yang, P.Y. Tam, B.J. Murray, T.M. McIntire, C.M. Overstreet, G.A. Weiss and R.M. Penner, Virus Electrodes for Universal Biodetection, Anal. Chem., 78 (2006) 3265-3270.

[73] H. Handa, S. Gurczynski, M.P. Jackson, G. Auner, J. Walker and G. Mao, Recognition of Salmonella typhimurium by immobilized phage P22 monolayers, Surf. Sci., 602 (2008) 1392-1400. [74] H. Handa, S. Gurczynski, M.P. Jackson and G. Mao, Immobilization and molecular interactions between bacteriophage and lipopolysaccharide bilayers, Langmuir, 26 (2010) 12095-12103.

[75] Y. Jia, M. Qin, H. Zhang, W. Niu, X. Li, L. Wang, X. Li, Y. Bai, Y. Cao and X. Feng, Label-free biosensor: A novel phage-modified Light Addressable Potentiometric Sensor system for cancer cell monitoring, Biosensors Bioelectron., 22 (2007) 3261-3266.

[76] N. Tawil, E. Sacher, R. Mandeville and M. Meunier, Strategies for the immobilization of bacteriophages on gold surfaces monitored by surface plasmon resonance and surface morphology, Journal of Physical Chemistry C, 117 (2013) 6686-6691.

[77] A. Shabani, C.A. Marquette, R. Mandeville and M.F. Lawrence, Magnetically-assisted impedimetric detection of bacteria using phage-modified carbon microarrays, Talanta, 116 (2013) 1047-1053.

[78] A. Shabani, M. Zourob, B. Allain, C.A. Marquette, M.F. Lawrence and R. Mandeville, Bacteriophage-modified microarrays for the direct impedimetric detection of bacteria, Anal. Chem., 80 (2008) 9475-9482.

[79] A. Shabani, C.A. Marquette, R. Mandeville and M.F. Lawrence, Carbon microarrays for the direct impedimetric detection of Bacillus anthracis using Gamma phages as probes, Analyst, 138 (2013) 14341440.

[80] C. Tlili, E. Sokullu, M. Safavieh, M. Tolba, M.U. Ahmed and M. Zourob, Bacteria screening, viability, and confirmation assays using bacteriophage-impedimetric/loop-mediated isothermal amplification dual-response biosensors, Anal. Chem., 85 (2013) 4893-4901. 
[81] S.K. Arya, A. Singh, R. Naidoo, P. Wu, M.T. McDermott and S. Evoy, Chemically immobilized T4bacteriophage for specific Escherichia coli detection using surface plasmon resonance, Analyst, 136 (2011) 486-492.

[82] A. Singh, N. Glass, M. Tolba, L. Brovko, M. Griffiths and S. Evoy, Immobilization of bacteriophages on gold surfaces for the specific capture of pathogens, Biosensors Bioelectron., 24 (2009) 3645-3651.

[83] L.A. Lee and Q. Wang, Adaptations of nanoscale viruses and other protein cages for medical applications, Nanomedicine, 2 (2006) 137-149.

[84] L.A. Lee, Z. Niu and Q. Wang, Viruses and virus-like protein assemblies-Chemically programmable nanoscale building blocks, Nano Research, 2 (2009) 349-364.

[85] F. He, M. Xiang and X. Mi, A new bacteriophage-modified piezoelectric sensor for rapid and specific detection of mycobacterium, Anal. Lett., 45 (2012) 1242-1253.

[86] N. Karoonuthaisiri, R. Charlermroj, M.J. Morton, M. Oplatowska-Stachowiak, I.R. Grant and C.T. Elliott, Development of a M13 bacteriophage-based SPR detection using Salmonella as a case study, Sensors and Actuators, B: Chemical, 190 (2014) 214-220.

[87] S.M. Tripathi, W.J. Bock, P. Mikulic, R. Chinnappan, A. Ng, M. Tolba and M. Zourob, Long period grating based biosensor for the detection of Escherichia coli bacteria, Biosensors Bioelectron., (2012).

[88] R. Guntupalli, I. Sorokulova, A. Krumnow, O. Pustovyy, E. Olsen and V. Vodyanoy, Real-time optical detection of methicillin-resistant Staphylococcus aureus using lytic phage probes, Biosensors Bioelectron., 24 (2008) 151-154.

[89] O.I. Guliy, B.D. Zaitsev, I.E. Kuznetsova, A.M. Shikhabudinov, O.A. Karavaeva, L.A. Dykman, S.A. Staroverov and O.V. Ignatov, Obtaining phage mini-antibodies and using them for detection of microbial cells with an electroacoustic sensor, Biophysics (Russian Federation), 57 (2012) 336-342. [90] M.T. Klem, D. Willits, M. Young and T. Douglas, 2-D array formation of genetically engineered viral cages on au surfaces and imaging by atomic force microscopy, J. Am. Chem. Soc., 125 (2003) 10806-10807.

[91] W. Sun, L. Brovko and M. Griffiths, Use of bioluminescent Salmonella for assessing the efficiency of constructed phage-based biosorbent, J. Ind. Microbiol. Biotechnol., 27 (2001) 126-128.

[92] V.A. Petrenko and P.K. Jayanna, Phage protein-targeted cancer nanomedicines, FEBS Lett., 588 (2014) 341-349.

[93] G.P. Smith and V.A. Petrenko, Phage display, Chem. Rev., 97 (1997) 391-410.

[94] H.M. Geysen, F. Schoenen, D. Wagner and R. Wagner, Combinatorial compound libraries for drug discovery: An ongoing challenge, Nature Reviews Drug Discovery, 2 (2003) 222-230.

[95] N. Malys, D.-Y. Chang, R.G. Baumann, D. Xie and L.W. Black, A bipartite bacteriophage T4 soc and hoc randomized peptide display library: Detection and analysis of phage T4 terminase (gp17) and late $\sigma$ factor (gp55) interaction, J. Mol. Biol., 319 (2002) 289-304.

[96] J.W. Lee, J. Song, M.P. Hwang and K.H. Lee, Nanoscale bacteriophage biosensors beyond phage display, International Journal of Nanomedicine, 8 (2013) 3917-3925.

[97] J.W. Kehoe and B.K. Kay, Filamentous phage display in the new millennium, Chem. Rev., 105 (2005) 4056-4072.

[98] M. Tolba, O. Minikh, L.Y. Brovko, S. Evoy and M.W. Griffiths, Oriented immobilization of bacteriophages for biosensor applications, Appl. Environ. Microbiol., 76 (2010) 528-535.

[99] Y. Ma, J.C. Pacan, Q. Wang, Y. Xu, X. Huang, A. Korenevsky and P.M. Sabour,

Microencapsulation of bacteriophage felix o1 into chitosan-alginate microspheres for oral delivery, Appl. Environ. Microbiol., 74 (2008) 4799-4805.

[100] K. Stanford, T.A. McAllister, Y.D. Niu, T.P. Stephens, A. Mazzocco, T.E. Waddell and R.P. Johnson, Oral delivery systems for encapsulated bacteriophages targeted escherichia coli o157: H7 in feedlot cattle, J. Food Prot., 73 (2010) 1304-1312.

[101] Y. Ma, J.C. Pacan, Q. Wang, P.M. Sabour, X. Huang and Y. Xu, Enhanced alginate microspheres as means of oral delivery of bacteriophage for reducing Staphylococcus aureus intestinal carriage, Food Hydrocolloids, 26 (2012) 434-440. 
[102] U. Puapermpoonsiri, J. Spencer and C.F. van der Walle, A freeze-dried formulation of bacteriophage encapsulated in biodegradable microspheres, Eur. J. Pharm. Biopharm., 72 (2009) 26-33. [103] M. Alfadhel, U. Puapermpoonsiri, S.J. Ford, F.J. McInnes and C.F. van der Walle, Lyophilized inserts for nasal administration harboring bacteriophage selective for Staphylococcus aureus: In vitro evaluation, Int. J. Pharm., 416 (2011) 280-287.

[104] K. Markoishvili, G. Tsitlanadze, R. Katsarava, J.G. Morris Jr and A. Sulakvelidze, A novel sustained-release matrix based on biodegradable poly(ester amide)s and impregnated with bacteriophages and an antibiotic shows promise in management of infected venous stasis ulcers and other poorly healing wounds, Int. J. Dermatol., 41 (2002) 453-458.

[105] K. Markoishvili, G. Tsitlanadze, R. Katsarava, J. Glenn and A. Sulakvelidze, A novel sustainedrelease matrix based on biodegradable poly(ester amide)s and impregnated with bacteriophages and an antibiotic shows promise in management of infected venous stasis ulcers and other poorly healing wounds, Int. J. Dermatol., 41 (2002) 453-458.

[106] R. Katsarava, V. Beridze, N. Arabuli, D. Kharadze, C.C. Chu and C.Y. Won, Amino acid-based bioanalogous polymers. Synthesis, and study of regular poly(ester amide)s based on bis(alpha-amino acid) alpha,omega-alkylene diesters, and aliphatic dicarboxylic acids, J. Polym. Sci. Pol. Chem., 37 (1999) 391-407.

[107] R. Korehei and J.F. Kadla, Encapsulation of T4 bacteriophage in electrospun poly(ethylene oxide)/cellulose diacetate fibers, Carbohydr. Polym., 100 (2014) 150-157.

[108] S.W. Lee and A.M. Belcher, Virus-based fabrication of micro- and nanofibers using electrospinning, Nano Lett., 4 (2004) 387-390.

[109] W. Salalha, J. Kuhn, Y. Dror and E. Zussman, Encapsulation of bacteria and viruses in electrospun nanofibres, Nanotechnology, 17 (2006) 4675-4681.

[110] Z. Tang, X. Huang, S. Baxi, J.R. Chambers, P.M. Sabour and Q. Wang, Whey protein improves survival and release characteristics of bacteriophage Felix $\mathrm{O} 1$ encapsulated in alginate microspheres, Food Res. Int., 52 (2013) 460-466.

[111] S. O'Flaherty, R.P. Ross, J. Flynn, W.J. Meaney, G.F. Fitzgerald and A. Coffey, Isolation and characterization of two anti-staphylococcal bacteriophages specific for pathogenic Staphylococcus aureus associated with bovine infections, Lett. Appl. Microbiol., 41 (2005) 482-486.

[112] J.J. Gill, J.C. Pacan, M.E. Carson, K.E. Leslie, M.W. Griffiths and P.M. Sabour, Efficacy and pharmacokinetics of bacteriophage therapy in treatment of subclinical Staphylococcus aureus mastitis in lactating dairy cattle, Antimicrob. Agents Chemother., 50 (2006) 2912-2918.

[113] G.W. Hanlon, S.P. Denyer, C.J. Olliff and L.J. Ibrahim, Reduction in exopolysaccharide viscosity as an aid to bacteriophage penetration through Pseudomonas aeruginosa biofilms, Appl. Environ. Microbiol., 67 (2001) 2746-2753.

[114] C. Dini, G.A. Islan, P.J. de Urraza and G.R. Castro, Novel biopolymer matrices for microencapsulation of phages: Enhanced protection against acidity and protease activity, Macromol. Biosci., 12 (2012) 1200-1208.

[115] Y. Lin, Z. Su, Z. Niu, S. Li, G. Kaur, L.A. Lee and Q. Wang, Layer-by-layer assembly of viral capsid for cell adhesion, Acta Biomater., 4 (2008) 838-843.

[116] Y. Lvov, H. Haas, G. Decher, H. Moehwald, A. Mikhailov, B. Mtchedlishvily, E. Morgunova and B. Vainshtein, Successive deposition of alternate layers of polyelectrolytes and a charged virus, Langmuir, 10 (1994) 4232-4236.

[117] N.F. Steinmetz, K.C. Findlay, T.R. Noel, R. Parker, G.P. Lomonossoff and D.J. Evans, Layer-bylayer assembly of viral nanoparticles and polyelectrolytes: the film architecture is different for spheres versus rods, ChemBioChem, 9 (2008) 1662-1670.

[118] P.A. Suci, M.T. Klem, F.T. Arce, T. Douglas and M. Young, Assembly of multilayer films incorporating a viral protein cage architecture, Langmuir, 22 (2006) 8891-8896.

[119] P.J. Yoo, K.T. Nam, J. Qi, S.-K. Lee, J. Park, A.M. Belcher and P.T. Hammond, Spontaneous assembly of viruses on multilayered polymer surfaces, Nat Mater, 5 (2006) 234-240. 
[120] P.J. Yoo, K.T. Nam, A.M. Belcher and P.T. Hammond, Solvent-assisted patterning of polyelectrolyte multilayers and selective deposition of virus assemblies, Nano Lett., 8 (2008) 1081-1089. [121] T. Jabrane, M. Dubé, M. Griffiths and P.J. Mangin, Towards a commercial production of phagebased bioactive paper, J-FOR, 1 (2011) 6-13.

[122] T. Jabrane, M. Dubé and P.J. Mangin, Bacteriophage activity on paper surface; effect of paper moisture, in: 8th World Congress of Chemical Engineering, Montreal, Qc, 2009.

[123] D.V. Dixon, Z. Hosseinidoust and N. Tufenkji, Effects of environmental and clinical interferents on the host capture efficiency of immobilized bacteriophages, Langmuir, 30 (2014) 3184-3190.

[124] T.G.M. van de Ven, Colloidal Hydrodynamics, Academic Press, London, 1989.

[125] J. Langlet, F. Gaboriaud, J. Duval and C. Gantzer, Aggregation and surface properties of F-specific RNA phages: Implication for membrane filtration processes, Water Res., 42 (2008) 2769-2777.

[126] R. Anders and C.V. Chrysikopoulos, Transport of viruses through saturated and unsaturated columns packed with sand, Transport in Porous Media, 76 (2009) 121-138.

[127] H. Cao, F.T.C. Tsai and K.A. Rusch, Impact of salinity on MS-2 sorption in saturated sand columns-fate and transport modeling, J. Environ. Eng., 135 (2009) 1041-1050.

[128] L. Cheng, A.S. Chetochine, I.L. Pepper and M.L. Brusseau, Influence of DOC on MS-2

bacteriophage transport in a sandy soil, Water, Air, Soil Pollut., 178 (2007) 315-322.

[129] Y. Chu, Y. Jin and M.V. Yates, Virus transport through saturated sand columns as affected by different buffer solutions, J. Environ. Qual., 29 (2000) 1103-1110.

[130] S.E. Dowd, S.D. Pillai, S. Wang and M.Y. Corapcioglu, Delineating the specific influence of virus isoelectric point and size on virus adsorption and transport through sandy soils, Appl. Environ.

Microbiol., 64 (1998) 405-410.

[131] C.P. Gerba, Virus survival and transport in groundwater, J. Ind. Microbiol. Biotechnol., 22 (1999) 535-539.

[132] C.M. Schaldach, W.L. Bourcier, H.F. Shaw, B.E. Viani and W.D. Wilson, The influence of ionic strength on the interaction of viruses with charged surfaces under environmental conditions, J. Colloid Interface Sci., 294 (2006) 1-10.

[133] S. Chattopadhyay and R.W. Puls, Forces dictating colloidal interactions between viruses and soil, Chemosphere, 41 (2000) 1279-1286.

[134] M.J. Archer and J.L. Liu, Bacteriophage T4 nanoparticles as materials in sensor applications: Variables that influence their organization and assembly on surfaces, Sensors, 9 (2009) 6298-6311.

[135] A.M. Bittner, Biomolecular rods and tubes in nanotechnology, Naturwissenschaften, 92 (2005) 5164.

[136] C.L. Cheung, S.-W. Chung, A. Chatterji, T. Lin, J.E. Johnson, S. Hok, J. Perkins and J.J. De

Yoreo, Physical controls on directed virus assembly at nanoscale chemical templates, J. Am. Chem. Soc., 128 (2006) 10801-10807.

[137] C.L. Cheung, A.I. Rubinstein, E.J. Peterson, A. Chatterji, R.F. Sabirianov, W.-N. Mei, T. Lin, J.E. Johnson and J.J. DeYoreo, Steric and electrostatic complementarity in the assembly of two-dimensional virus arrays, Langmuir, 26 (2009) 3498-3505.

[138] D.J. Evans, The bionanoscience of plant viruses: Templates and synthons for new materials, J. Mater. Chem., 18 (2008) 3746-3754.

[139] J.X. Tang, T. Ito, T. Tao, P. Traub and P.A. Janmey, Opposite effects of electrostatics and steric exclusion on bundle formation by F-actin and other filamentous polyelectrolytes, Biochemistry, 36 (1997) 12600-12607.

[140] S.A. Overman, D.M. Kristensen, P. Bondre, B. Hewitt and G.J. Thomas Jr, Effects of virion and salt concentrations on the raman signatures of filamentous phages fd, $\mathrm{Pf} 1, \mathrm{Pf} 3$, and $\mathrm{PH} 75^{+}$, Biochemistry, 43 (2004) 13129-13136.

[141] Q. Wen and J.X. Tang, Temperature effects on threshold counterion concentration to induce aggregation of fd virus, Phys. Rev. Lett., 97 (2006). 
[142] S. Huang, H. Yang, M.L. Johnson, R.S. Lakshinanan, I. Chen, V.A. Petrenko, J.M. Barbaree, B.A. Chin and Ieee, The effect of phage solution chemistry on the spore binding affinity of magnetoelastic biosensors, in: 2007 Ieee Sensors, Vols 1-3, 2007, pp. 1093-1096.

[143] E.M. van Voorthuizen, N.J. Ashbolt and A.I. Schäfer, Role of hydrophobic and electrostatic interactions for initial enteric virus retention by MF membranes, J. Membr. Sci., 194 (2001) 69-79.

[144] S.R. Farrah, D.O. Shah and L.O. Ingram, Effects of chaotropic and antichaotropic agents on elution of poliovirus adsorbed on membrane filters, Proc. Natl. Acad. Sci. U. S. A., 78 (1981) 1229-1232.

[145] L. Gervais, M. Gel, B. Allain, M. Tolba, L. Brovko, M. Zourob, R. Mandeville, M. Griffiths and S. Evoy, Immobilization of biotinylated bacteriophages on biosensor surfaces, Sensors and Actuators, B:

Chemical, 125 (2007) 615-621.

[146] Z. Hosseinidoust, T.G. van de Ven and N. Tufenkji, Bacterial capture efficiency and antimicrobial activity of phage-functionalized model surfaces, Langmuir, 27 (2011) 5472-5480.

[147] Z. Li, M. Tolba, M. Griffiths and T.G.M. van de Ven, Effect of unassembled phage protein complexes on the attachment to cellulose of genetically modified bacteriophages containing cellulose binding modules, Colloids Surf. B. Biointerfaces, 76 (2010) 529-534.

[148] H. Zhu, I.M. White, J.D. Suter and X. Fan, Phage-based label-free biomolecule detection in an opto-fluidic ring resonator, Biosensors Bioelectron., 24 (2008) 461-466.

[149] P.M. Boltovets, B.A. Snopok, V.R. Boyko, T.P. Shevchenko, N.S. Dyachenko and Y.M. Shirshov, Detection of plant viruses using a surface plasmon resonance via complexing with specific antibodies, J. Virol. Methods, 121 (2004) 101-106.

[150] N. Tawil, E. Sacher, R. Mandeville and M. Meunier, Surface plasmon resonance detection of $E$. coli and methicillin-resistant S. aureus using bacteriophages, Biosensors Bioelectron., 37 (2012) 24-29.

[151] A.L.J. Olsson, H.C. van der Mei, H.J. Busscher and P.K. Sharma, Acoustic sensing of the bacterium-substratum interface using QCM-D and the influence of extracellular polymeric substances, J. Colloid Interface Sci., 357 (2011) 135-138.

[152] E.V. Olsen, S.T. Pathirana, A.M. Samoylov, J.M. Barbaree, B.A. Chin, W.C. Neely and V. Vodyanoy, Specific and selective biosensor for Salmonella and its detection in the environment, J. Microbiol. Methods, 53 (2003) 273-285.

[153] A.L.J. Olsson, H.C. Van Der Mei, D. Johannsmann, H.J. Busscher and P.K. Sharma, Probing colloid-substratum contact stiffness by acoustic sensing in a liquid phase, Anal. Chem., 84 (2012) 45044512.

[154] G.L. Dybwad, A sensitive new method for the determination of adhesive bonding between a particle and a substrate, J. Appl. Phys., 58 (1985) 2789-2790.

[155] A. Pomorska, D. Shchukin, R. Hammond, M.A. Cooper, G. Grundmeier and D. Johannsmann, Positive frequency shifts observed upon adsorbing micron-sized solid objects to a quartz crystal microbalance from the liquid phase, Anal. Chem., 82 (2010) 2237-2242.

[156] R. Guntupalli, I. Sorokulova, E. Olsen, L. Globa, O. Pustovyy, T. Moore, B. Chin, J. Barbaree and V. Vodyanoy, Detection and identification of methicillin resistant and sensitive strains of Staphylococcus aureus using tandem measurements, J. Microbiol. Methods, 90 (2012) 182-191.

[157] R. Naidoo, A. Singh, S.K. Arya, B. Beadle, N. Glass, J. Tanha, C.M. Szymanski and S. Evoy, Surface-immobilization of chromatographically purified bacteriophages for the optimized capture of bacteria, Bacteriophage, 2 (2012) 15-24.

[158] Duckwort.Dh, Biological activity of bacteriophage ghosts and take-over of host functions by bacteriophage, Bacteriol. Rev., 34 (1970) 344-\&.

[159] A.K. Trilling, M.M. Harmsen, V.J.B. Ruigrok, H. Zuilhof and J. Beekwilder, The effect of uniform capture molecule orientation on biosensor sensitivity: Dependence on analyte properties, Biosensors Bioelectron., 40 (2013) 219-226.

[160] P. Serwer, Agarose gel electrophoresis of bacteriophages and related particles, Journal of Chromatography B: Biomedical Sciences and Applications, 418 (1987) 345-357. 
[161] J.-H. Han, M.S. Wang, J. Das, L.M. Sudheendra, E. Vonasek, N. Nitin and I.M. Kennedy, The capture and detection of T7 bacteriophages on a nanostructured interface, ACS Applied Materials \& Interfaces, (2014).

[162] H.J. Um, M. Kim, S.H. Lee, J. Min, H. Kim, Y.W. Choi and Y.H. Kim, Electrochemically oriented immobilization of antibody on poly-(2-cyano-ethylpyrrole)-coated gold electrode using a cyclic voltammetry, Talanta, 84 (2011) 330-334.

[163] B. Peng, N. Liu, Y. Lin, L. Wang, W. Zhang, Z. Niu, Q. Wang and Z. Su, Self-assembly of anisotropic tobacco mosaic virus nanoparticles on gold substrate, Science China Chemistry, 54 (2011) 137-143.

[164] M.F. Cuddy, A.R. Poda and L.N. Brantley, Determination of isoelectric points and the role of ph for common Quartz Crystal Microbalance sensors, ACS Applied Materials \& Interfaces, 5 (2013) 35143518.

[165] G. Wulff, Molecular imprinting in cross-linked materials with the aid of molecular templates - a way towards artificial antibodies, Angewandte Chemie-International Edition in English, 34 (1995) 18121832.

[166] O. Hayden, P.A. Lieberzeit, D. Blaas and F.L. Dickert, Artificial antibodies for bioanalyte detection - Sensing viruses and proteins, Adv. Funct. Mater., 16 (2006) 1269-1278.

[167] N. Sankarakumar and Y.W. Tong, Preventing viral infections with polymeric virus catchers: A novel nanotechnological approach to anti-viral therapy, Journal of Materials Chemistry B, 1 (2013) 20312037.

[168] Y. Lin, A. Böker, H. Skaff, D. Cookson, A.D. Dinsmore, T. Emrick and T.P. Russell, Nanoparticle assembly at fluid interfaces: Structure and dynamics, Langmuir, 21 (2005) 191-194.

[169] J. He, Z. Niu, R. Tangirala, J.Y. Wang, X. Wei, G. Kaur, Q. Wang, G. Jutz, A. Böker, B. Lee, S.V. Pingali, P. Thiyagarajan, T. Emrick and T.P. Russell, Self-assembly of tobacco mosaic virus at oil/water interfaces, Langmuir, 25 (2009) 4979-4987.

[170] I. Langmuir, The constitution and fundamental properties of solids and liquids, J. Am. Chem. Soc., 39 (1917) 1848-1906.

[171] G.G. Roberts, Applied science perspective of langmuir-blodgett films, Advances in Physics, 34 (1985) 475-512.

[172] R. Guntupalli, I. Sorokulova, R. Long, E. Olsen, W. Neely and V. Vodyanoy, Phage Langmuir monolayers and Langmuir-Blodgett films, Colloids Surf. B. Biointerfaces, 82 (2011) 182-189.

[173] T. Sawada and T. Serizawa, Immobilization of highly oriented filamentous viruses onto polymer substrates, Journal of Materials Chemistry B, 1 (2013) 149-152.

[174] D.-Y. Jeon, K.H. Hwang, S.-J. Park, Y.-J. Kim, M.-K. Joo, S.-E. Ahn, G.-T. Kim and C.-H. Nam, Controlled surface adsorption of fd filamentous phage by tuning of the $\mathrm{pH}$ and the functionalization of the surface, J. Appl. Phys., 109 (2011) -.

[175] J.F. Allemand, D. Bensimon, L. Jullien, A. Bensimon and V. Croquette, pH-dependent specific binding and combing of DNA, Biophys. J., 73 (1997) 2064-2070.

[176] J. Rong, Z. Niu, L.A. Lee and Q. Wang, Self-assembly of viral particles, Current Opinion in Colloid \& Interface Science, 16 (2011) 441-450.

[177] Y. Lin, E. Balizan, L.A. Lee, Z. Niu and Q. Wang, Self-assembly of rodlike bio-nanoparticles in capillary tubes, Angew. Chem. Int. Ed., 49 (2010) 868-872.

[178] Y. Lin, Z. Su, G. Xiao, E. Balizan, G. Kaur, Z. Niu and Q. Wang, Self-assembly of virus particles on flat surfaces via controlled evaporation, Langmuir, 27 (2010) 1398-1402.

[179] S.P. Wargacki, B. Pate and R.A. Vaia, Fabrication of $2 d$ ordered films of tobacco mosaic virus (TMV): Processing morphology correlations for convective assembly, Langmuir, 24 (2008) 5439-5444.

[180] J. Rong, L.A. Lee, K. Li, B. Harp, C.M. Mello, Z. Niu and Q. Wang, Oriented cell growth on selfassembled bacteriophage M13 thin films, Chem. Commun., (2008) 5185-5187.

[181] Z. Matharu, A.J. Bandodkar, V. Gupta and B.D. Malhotra, Fundamentals and application of ordered molecular assemblies to affinity biosensing, Chem. Soc. Rev., 41 (2012) 1363-1402. 
[182] A. Kumar and G.M. Whitesides, Features of gold having micrometer to centimeter dimensions can be formed through a combination of stamping with an elastomeric stamp and an alkanethiol "ink" followed by chemical etching, Appl. Phys. Lett., 63 (1993) 2002-2004.

[183] A. Horn, S. Hiltl, A. Fery and A. Böker, Ordering and printing virus arrays: A straightforward way to functionalize surfaces, Small, 6 (2010) 2122-2125.

[184] S. Balci, D.M. Leinberger, M. Knez, A.M. Bittner, F. Boes, A. Kadri, C. Wege, H. Jeske and K. Kern, Printing and aligning mesoscale patterns of Tobacco mosaic virus on surfaces, Adv. Mater., 20 (2008) 2195-2200.

[185] B. Feng, S. Huang, F. Ge, Y. Luo, D. Jia and Y. Dai, 3D antibody immobilization on a planar matrix surface, Biosensors Bioelectron., 28 (2011) 91-96.

[186] B.N. Johnson and R. Mutharasan, pH effect on protein $\mathrm{G}$ orientation on gold surfaces and characterization of adsorption thermodynamics, Langmuir, 28 (2012) 6928-6934.

[187] E.S. Kim, C.K. Shim, J.W. Lee, J.W. Park and K.Y. Choi, Synergistic effect of orientation and lateral spacing of protein G on an on-chip immunoassay, Analyst, 137 (2012) 2421-2430.

[188] H.X. Chen, J.Y. Huang, J. Lee, S. Hwang and K. Koh, Surface plasmon resonance spectroscopic characterization of antibody orientation and activity on the calixarene monolayer, Sens. Actuator BChem., 147 (2010) 548-553.

[189] M.C. Coen, R. Lehmann, P. Groning, M. Bielmann, C. Galli and L. Schlapbach, Adsorption and bioactivity of protein a on silicon surfaces studied by AFM and XPS, J. Colloid Interface Sci., 233 (2001) 180-189.

[190] P. Dutta, S. Sawoo, N. Ray, O. Bouloussa and A. Sarkar, Engineering bioactive surfaces with Fischer carbene complex: protein A on self-assembled monolayer for antibody sensing, Bioconjug. Chem., 22 (2011) 1202-1209.

[191] S. Kumar, R. Ch, D. Rath and S. Panda, Densities and orientations of antibodies on nano-textured silicon surfaces, Mat Sci Eng C-Mater, 31 (2011) 370-376.

[192] K. Yoshimoto, M. Nishio, H. Sugasawa and Y. Nagasaki, Direct observation of adsorption-induced inactivation of antibody fragments surrounded by mixed-PEG layer on a gold surface, J. Am. Chem. Soc., 132 (2010) 7982-7989.

[193] M. Gaczynska and P.A. Osmulski, AFM of biological complexes: What can we learn?, Current Opinion in Colloid and Interface Science, 13 (2008) 351-367.

[194] A.L.J. Olsson, I.R. Quevedo, D. He, M. Basnet and N. Tufenkji, Using the quartz crystal microbalance with dissipation monitoring to evaluate the size of nanoparticles deposited on surfaces, ACS Nano, 7 (2013) 7833-7843.

[195] H. Chen, X. Su, K.-G. Neoh and W.-S. Choe, QCM-D analysis of binding mechanism of phage particles displaying a constrained heptapeptide with specific affinity to $\mathrm{SiO}_{2}$ and $\mathrm{TiO}_{2}$, Anal. Chem., 78 (2006) 4872-4879.

[196] K.-I. Sano and K. Shiba, A hexapeptide motif that electrostatically binds to the surface of titanium, J. Am. Chem. Soc., 125 (2003) 14234-14235.

[197] C.L. Wong and M. Olivo, Surface Plasmon Resonance Imaging Sensors: A Review, Plasmonics, (2014) 1-16.

[198] H. Chen, J. Huang, J. Lee, S. Hwang and K. Koh, Surface plasmon resonance spectroscopic characterization of antibody orientation and activity on the calixarene monolayer, Sensors and Actuators, B: Chemical, 147 (2010) 548-553.

[199] J.R. Lu, E.M. Lee and R.K. Thomas, The analysis and interpretation of neutron and X-ray specular reflection, Acta Crystallogr. Sect. A: Found. Crystallogr., 52 (1996) 11-41.

[200] A.P. Le Brun, S.A. Holt, D.S.H. Shah, C.F. Majkrzak and J.H. Lakey, The structural orientation of antibody layers bound to engineered biosensor surfaces, Biomaterials, 32 (2011) 3303-3311.

[201] X. Zhao, F. Pan, B. Cowsill, J.R. Lu, L. Garcia-Gancedo, A.J. Flewitt, G.M. Ashley and J. Luo, Interfacial immobilization of monoclonal antibody and detection of human prostate-specific antigen, Langmuir, 27 (2011) 7654-7662. 
[202] A.K. Trilling, J. Beekwilder and H. Zuilhof, Antibody orientation on biosensor surfaces: a minireview, Analyst, 138 (2013) 1619-1627.

[203] H.Y. Song, X. Zhou, J. Hobley and X. Su, Comparative study of random and oriented antibody immobilization as measured by dual polarization interferometry and surface plasmon resonance spectroscopy, Langmuir, 28 (2012) 997-1004.

[204] J. Ortega-Arroyo and P. Kukura, Interferometric scattering microscopy (iSCAT): New frontiers in ultrafast and ultrasensitive optical microscopy, PCCP, 14 (2012) 15625-15636.

[205] Z.M. Xia and T.G.M. Vandeven, Adhesion kinetics of phosphatidylcholine liposomes by evanescent wave light-scattering, Langmuir, 8 (1992) 2938-2946.

[206] P. Kukura, H. Ewers, C. Müller, A. Renn, A. Helenius and V. Sandoghdar, High-speed nanoscopic tracking of the position and orientation of a single virus, Nat. Methods, 6 (2009) 923-927.

[207] M.S. Wagner and D.G. Castner, Analysis of adsorbed proteins by static time-of-flight secondary ion mass spectrometry, Appl. Surf. Sci., 231-232 (2004) 366-376.

[208] J.E. Baio, F. Cheng, D.M. Ratner, P.S. Stayton and D.G. Castner, Probing orientation of immobilized humanized anti-lysozyme variable fragment by time-of-flight secondary-ion mass spectrometry, Journal of Biomedical Materials Research - Part A, 97 A (2011) 1-7.

[209] I.H. Cho, J.W. Park, T.G. Lee, H. Lee and S.H. Paek, Biophysical characterization of the molecular orientation of an antibody-immobilized layer using secondary ion mass spectrometry, Analyst, 136 (2011) 1412-1419.

[210] J.W. Park, I.H. Cho, D.W. Moon, S.H. Paek and T.G. Lee, ToF-SIMS and PCA of surfaceimmobilized antibodies with different orientations, Surf. Interface Anal., 43 (2011) 285-289.

[211] F. Liu, M. Dubey, H. Takahashi, D.G. Castner and D.W. Grainger, Immobilized antibody orientation analysis using secondary ion mass spectrometry and fluorescence imaging of affinitygenerated patterns, Anal. Chem., 82 (2010) 2947-2958.

[212] Z. Hosseinidoust, N. Tufenkji and T.G.M. van de Ven, Formation of biofilms under phage predation: considerations concerning a biofilm increase, Biofouling, 29 (2013) 457-468.

[213] Z. Hosseinidoust, N. Tufenkji and T.G. van de Ven, Predation in homogeneous and heterogeneous phage environments affects virulence determinants of Pseudomonas aeruginosa, Appl. Environ. Microbiol., 79 (2013) 2862-2871.

[214] Z. Hosseinidoust, T.G. van de Ven and N. Tufenkji, Evolution of Pseudomonas aeruginosa virulence as a result of phage predation, Appl. Environ. Microbiol., 79 (2013) 6110-6116. 


\section{Figures}

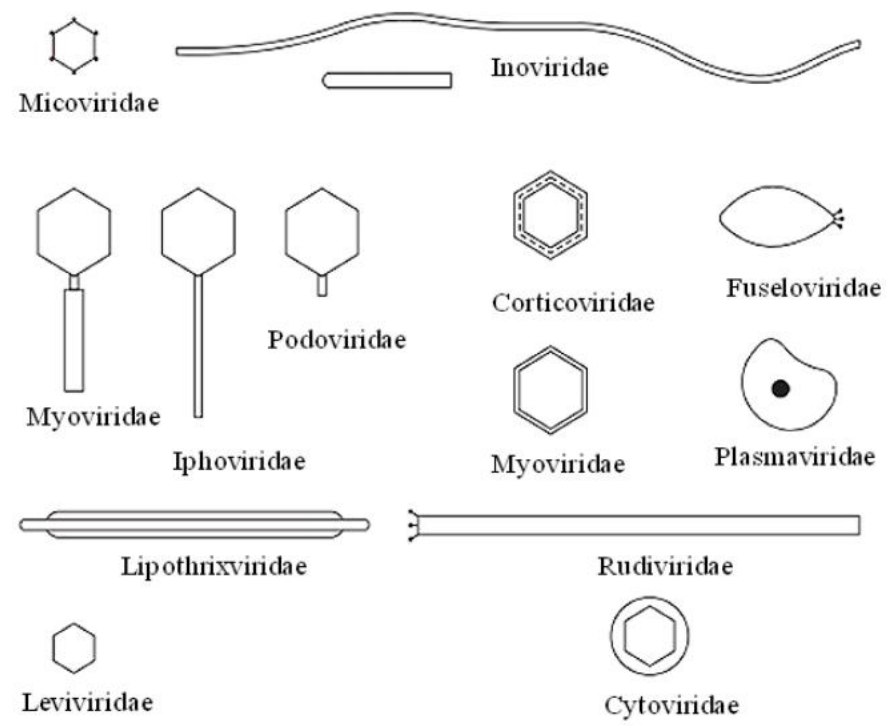

Figure 1. Schematic representation of major phage groups. Reproduced from ref. [25] with permission from Oxford University Press, USA. 


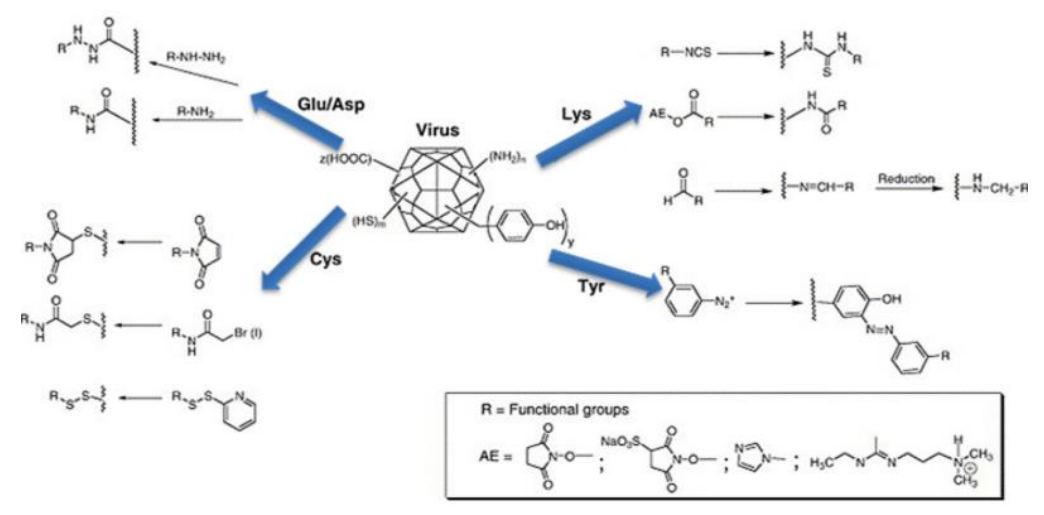

Figure 2. Conventional protein conjugation strategies targeting the endogenous amino acids (lysine, cysteine, aspartic or glutamic acids, and tyrosine) on virus particles. Reproduced with permission from ref. [83].

(a)

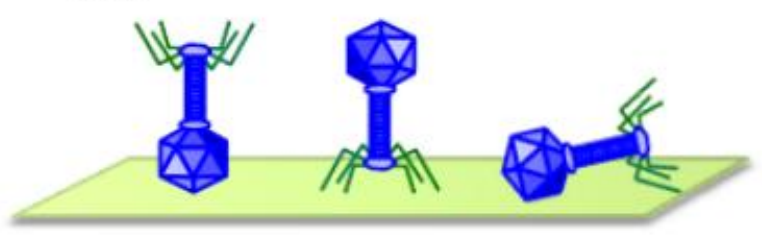

(c)

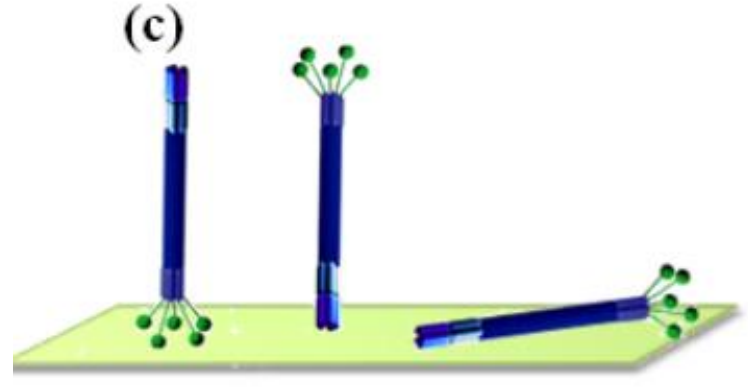

(b)

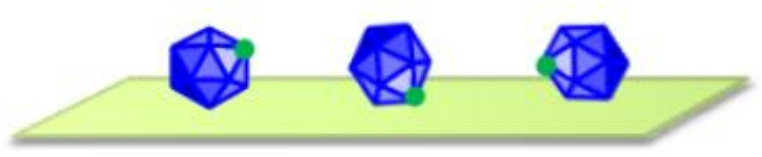

(d)

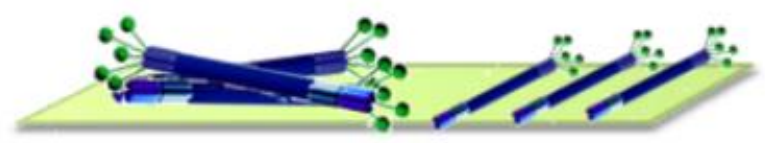

Figure 3. Schematic illustration of various possible orientations of phage on surface. The bacterial capture proteins are marked in green (a) tailed phage can adsorb head-down, tail-down or side-ways, (b) icosahedral asymmetric phage, (c) filamentous phage can adsorb via either pole or side-ways, (d) filamentous phage are prone to bundling or aggregation (left), efforts to orient them typically focus on arranging them parallel on the substrate (right). 
(a)

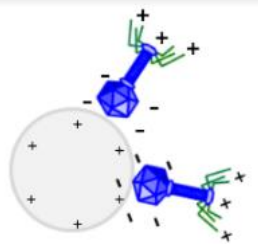

(c)

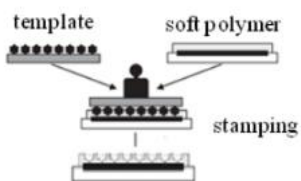

(e)

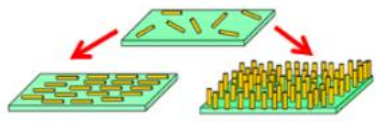

(g)

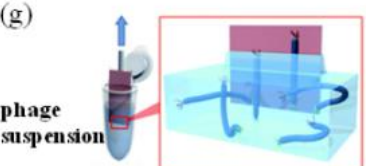

(i)

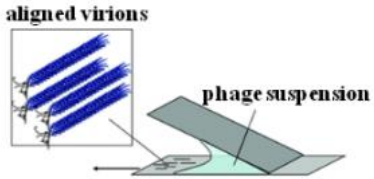

(b)

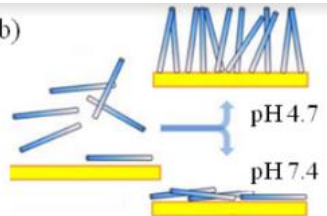

(d)

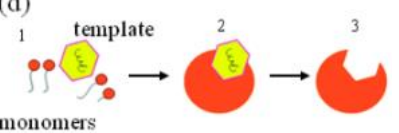

(f)

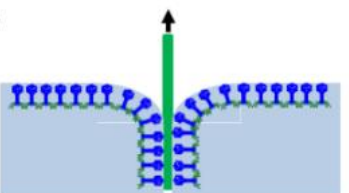

(h) phage suspension

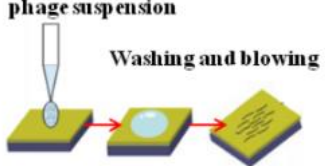

(j)

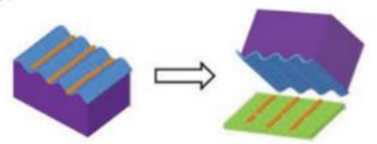

Figure 4. Various methods of orienting phage: (a) electrostatic, (b) assembly at liquid-liquid interface, reproduced with permission from ref. [163], (c) molecular imprinting, reproduced with permission from ref. [167] (d) molecular imprinting, reproduced with permission from ref. [166], (e) assembly at liquidliquid interface, reproduced with permission from ref. [169], (f) Langmuir-Blodgett film, (g) shearassisted alignment, reproduced with permission from ref. [173], (h) drying alignment, reproduced with permission from ref. [174], (i) capillary-assisted assembly, reproduced with permission from ref. [180], (j) micro-contact printing, reproduced with permission from ref. [183]. 
(a)

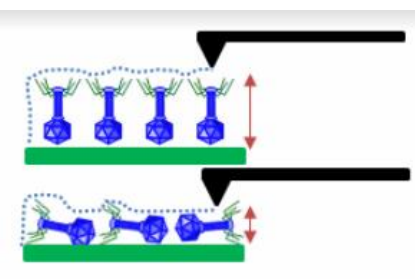

(c)
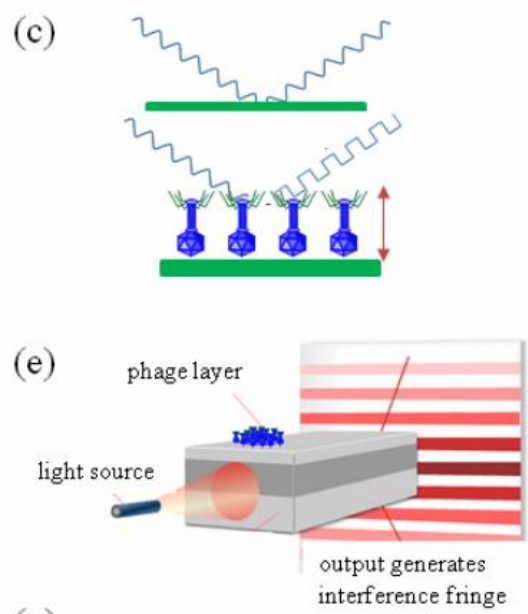

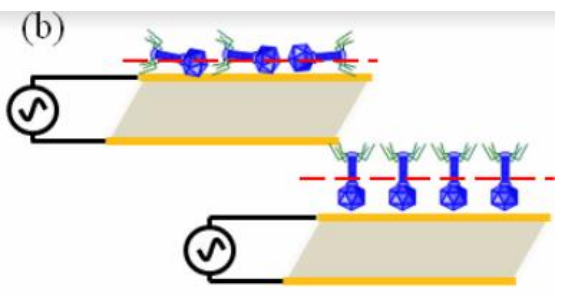

(d)

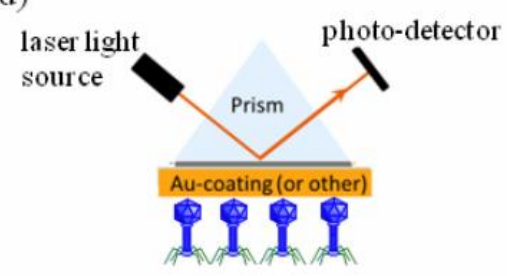

(f)

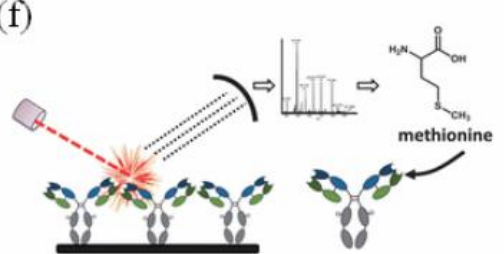

D.
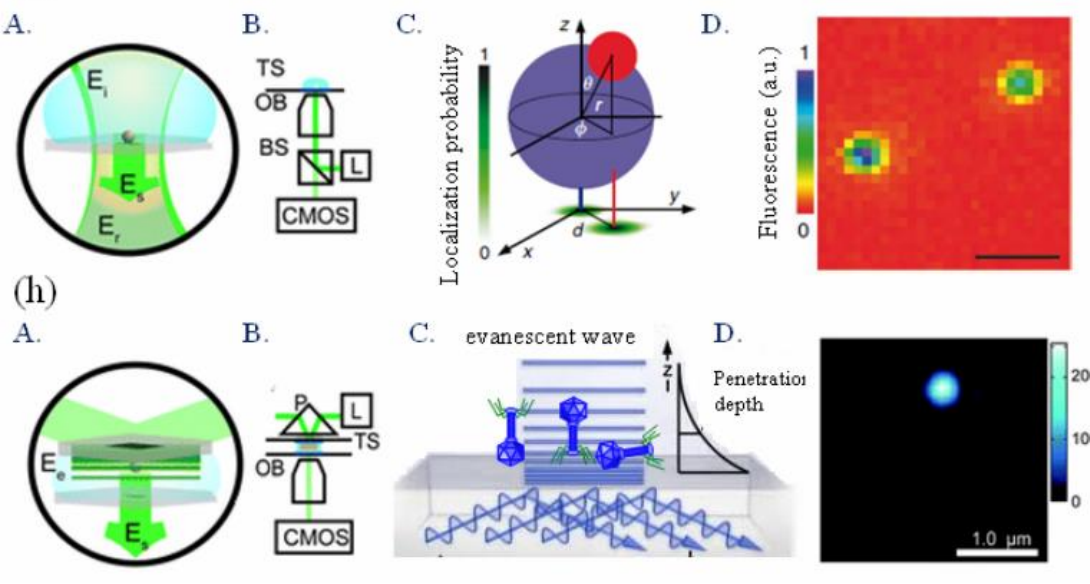

C.

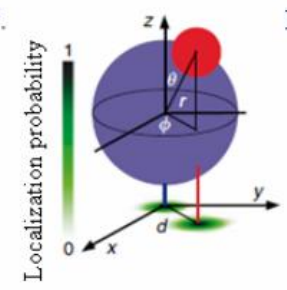

(h)

B.

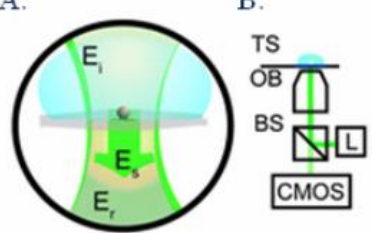

C. evanescent wave, D.

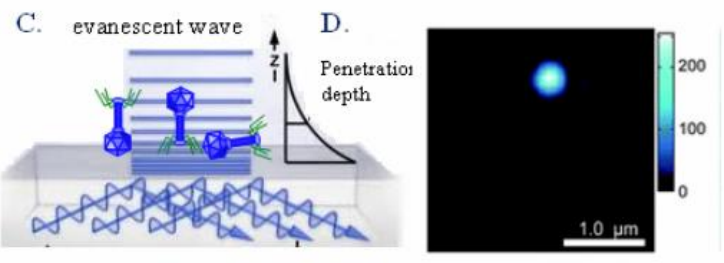

Figure 5. Various methods of characterizing phage orientation: (a) atomic force microscopy, (b) quartz crystal microbalance, (c) spectroscopic ellipsometry and neutron reflectometry, (d) ellipsometry, (e) dual position interferometry, ( $f$ ) time-of-flight secondary ion mass spectrometry (ToF-SIMS), reproduced with permission from ref. [202], (g) interferometric scattering microscopy (iSCAT), A. Schematic diagram for iSCAT signal generation: objective tightly focuses the incident light (Ei) onto the sample and collects the

light reflected $(E r)$ at the glass coverslip interface and the light backscattered by particles within the illumination region (Es), B. iSCAT optics: beam splitter (BS), prism (P), translation stage (TS), objective $(O B), C M O S$ camera (CMOS), C. Determination of the distance, $d$, the polar angle, theta, and the azimuthal angle, phi, of a virus (blue) bound by a quantum dot (red) from the scattering and fluorescence centers of mass obtained by localization (green), D. Representative interferometric scattering image of viral nanoparticles, Scale bars, 1 m, (b) total internal reflection dark field microscopy (TIRDM), $A$. 
Schematic diagram for TIRDM signal generation: objective collects the light forward scattered (Es) by particles within the evanescent field (Ee) produced by total internal reflection, B. optics, C. schematic of the evanescent wave field penetration depth, D. Image of a $40 \mathrm{~nm}$ gold particle obtained by TIRDFM. $g$ and $h$, reproduced with permission from refs. [204, 206]. 


\section{Tables}

Table 1. Phage-functionalized surfaces for biosensor design

\begin{tabular}{|c|c|c|c|c|c|c|}
\hline $\begin{array}{c}\text { Means of } \\
\text { transduction }\end{array}$ & Host organism & Phage & Geometry & $\begin{array}{c}\text { Means of } \\
\text { immobilization }\end{array}$ & $\begin{array}{l}\text { Detection } \\
\text { limit }\end{array}$ & Reference \\
\hline \multirow{4}{*}{ QCM } & S. aureus & 12600 & tailed & physisorption & n.a. & [156] \\
\hline & $\begin{array}{l}\text { M. smegmatis, } \\
\text { M. tuberculosis }\end{array}$ & D29 & tailed & covalent & $10^{3} \mathrm{cfu} / \mathrm{mL}$ & {$[85]$} \\
\hline & S. Typhimurium & E2 & filamentous & physisorption & $10^{2} \mathrm{cfu} / \mathrm{mL}$ & [61] \\
\hline & S. Typhimurium & E2 & filamentous & physisorption & $10^{2} \mathrm{cfu} / \mathrm{mL}$ & [152] \\
\hline $\begin{array}{l}\text { Magnetostrictive } \\
\text { cantilever }\end{array}$ & B. anthracis & JRB7 & filamentous & physisorption & $10^{4} \mathrm{cfu} / \mathrm{mL}$ & {$[43]$} \\
\hline \multirow{7}{*}{ Magnetoelastic } & S. Typhimurium & E2 & filamentous & physisorption & $\begin{array}{l}5 \times 10^{2} \\
\mathrm{cfu} / \mathrm{mL}\end{array}$ & {$[46]$} \\
\hline & S. Typhimurium & E2 & filamentous & physisorption & $<50 \mathrm{cfu} / \mathrm{mL}$ & {$[67]$} \\
\hline & S. Typhimurium & E2 & filamentous & physisorption & $\begin{array}{l}5 \times 10^{3} \\
\mathrm{cfu} / \mathrm{mL}\end{array}$ & {$[62]$} \\
\hline & S. Typhimurium & E2 & filamentous & physisorption & $10^{3} \mathrm{cfu} / \mathrm{mL}$ & {$[45]$} \\
\hline & B. anthracis & JRB7 & filamentous & physisorption & $\begin{array}{l}5 \times 10^{3} \\
\mathrm{cfu} / \mathrm{mL}\end{array}$ & {$[42]$} \\
\hline & B. anthracis & JRB7 & filamentous & physisorption & $10^{3}$ spores $/ \mathrm{mL}$ & {$[63]$} \\
\hline & B. anthracis & JRB7 & filamentous & physisorption & $\begin{array}{c}10^{3} \\
\text { spores } / \mathrm{mL}\end{array}$ & [44] \\
\hline Electroacoustic & A. brasilense Sp 245 & $\mathrm{~m} 13$ & filamentous & covalent & $10^{3} \mathrm{cfu} / \mathrm{mL}$ & [89] \\
\hline \multirow{6}{*}{ Impedance } & E. coli & $\mathrm{T} 4$ & tailed & covalent & n.a. & [145] \\
\hline & E. coli & T4 & tailed & physisorption & $\begin{array}{l}10^{4}-10^{7} \\
\mathrm{cfu} / \mathrm{mL}\end{array}$ & {$[64]$} \\
\hline & E. coli & T4 & tailed & covalent & $\begin{array}{l}10^{3}-10^{4} \\
\mathrm{cfu} / \mathrm{mL}\end{array}$ & [77] \\
\hline & E. coli & T4 & tailed & covalent & $\begin{array}{l}2 \times 10^{4} \\
\mathrm{cfu} / \mathrm{mL}\end{array}$ & [78] \\
\hline & E. coli & T4 & tailed & covalent & $\begin{array}{l}8 \times 10^{2} \\
\mathrm{cfu} / \mathrm{mL}\end{array}$ & {$[80]$} \\
\hline & B. anthracis & Gamma & tailed & covalent & $10^{3} \mathrm{cfu} / \mathrm{mL}$ & [79] \\
\hline \multirow{7}{*}{ SPR } & S. aureus & 12600 & tailed & physisorption & $10^{4} \mathrm{cfu} / \mathrm{mL}$ & {$[58]$} \\
\hline & Salmonella & M13 & filamentous & covalent & $\begin{array}{l}10^{7}-10^{8} \\
\mathrm{cfu} / \mathrm{mL}\end{array}$ & [86] \\
\hline & L. monocytogenes & $\begin{array}{c}\mathrm{Lm} \\
\mathrm{P} 4: \mathrm{A} 8\end{array}$ & filamentous & physisorption & $\begin{array}{l}2 \times 10^{6} \\
\mathrm{cfu} / \mathrm{mL}\end{array}$ & [65] \\
\hline & E. coli & T4 & tailed & covalent & $\begin{array}{l}7 \times 10^{2} \\
\mathrm{cfu} / \mathrm{mL}\end{array}$ & [81] \\
\hline & E. coli & $\mathrm{T} 4$ & tailed & covalent & n.a. & \multirow{3}{*}{ [157] } \\
\hline & Salmonella & P22 & tailed & covalent & n.a. & \\
\hline & C. jejuni & $\begin{array}{l}\text { NCTC } \\
12673\end{array}$ & tailed & covalent & n.a. & \\
\hline
\end{tabular}




\begin{tabular}{ccccccc} 
& E. coli & T4 & tailed & covalent & $10^{3} \mathrm{cfu} / \mathrm{mL}$ & {$[150]$} \\
& S. aureus & BP14 & tailed & covalent & $10^{3} \mathrm{cfu} / \mathrm{mL}$ & \\
\hline \multirow{3}{*}{ Fiber optics } & E. coli & T4 & tailed & physisorption & $10^{4} \mathrm{cfu} / \mathrm{mL}$ & {$[66]$} \\
& E. coli & T4 & tailed & physisorption & n.a. & {$[56]$} \\
& E. coli & T4 & tailed & covalent & $10^{3} \mathrm{cfu} / \mathrm{mL}$ & {$[87]$} \\
\hline
\end{tabular}

n.a.: not available 
Table 2. Phage-functionalized surfaces for bacterial capture

\begin{tabular}{|c|c|c|c|c|c|c|c|c|}
\hline Surface & Phage & $\begin{array}{l}\text { Phage } \\
\text { geometry }\end{array}$ & Host organism & $\begin{array}{c}\text { Means of } \\
\text { immobilization }\end{array}$ & $\begin{array}{l}\text { Phage } \\
\text { surface } \\
\text { coverage }\end{array}$ & Bacterial capture & Notable findings & Reference \\
\hline Glass slide & $\begin{array}{l}\text { ATCC } \\
12600\end{array}$ & tailed & S. aureus & covalent & n.a. & $0.01-33 \% *$ & & [88] \\
\hline Glass slide & P22 & tailed & S. Typhimurium & covalent & $12-67 \% *$ & $3-16 \% *$ & $\begin{array}{l}\text { Bacterial capture } \\
\text { efficiency per phage } \\
\text { decreased with phage } \\
\text { surface coverage }\end{array}$ & {$[73]$} \\
\hline Gold & T4 & tailed & E. coli & $\begin{array}{l}\text { physisorption } \\
\text { covalent }\end{array}$ & $\begin{array}{l}0.3 \mu \mathrm{m}^{-2} \\
4.4 \mu \mathrm{m}^{-2}\end{array}$ & $\begin{array}{c}0.13 \times 100^{-1} \mu \mathrm{m}^{-2} \\
\text { n.a. }\end{array}$ & $\begin{array}{l}\text { 15-fold improvement } \\
\text { in capture efficiency } \\
\text { compared to the } \\
\text { simple physisorption }\end{array}$ & {$[145]$} \\
\hline Gold & $\mathrm{T} 4$ & tailed & E. coli & covalent & n.a. & 17 & & [81] \\
\hline Gold & $\begin{array}{c}\text { T4 } \\
\text { P22 } \\
\text { NCTC } \\
12673\end{array}$ & tailed & $\begin{array}{c}\text { E. coli } \\
\text { S. Typhimurium } \\
\text { C. jejuni }\end{array}$ & covalent & $\begin{array}{c}19 \times \mu \mathrm{m}^{-2} \\
10 \times \mu \mathrm{m}^{-2} \\
1.37 \times \mu \mathrm{m}^{-2}\end{array}$ & $\begin{array}{l}18 \times 100^{-1} \mu \mathrm{m}^{-2} \\
4.1 \times 100^{-1} \mu \mathrm{m}^{-2} \\
46 \times 100^{-1} \mu \mathrm{m}^{-2}\end{array}$ & $\begin{array}{l}\text { Reported values are } \\
\text { optimal phage surface } \\
\text { coverage for maxium } \\
\text { bacterial capture. }\end{array}$ & {$[157]$} \\
\hline Gold & $\mathrm{T} 4$ & tailed & E. coli & $\begin{array}{l}\text { physisorption } \\
\text { via dextrose } \\
\text { via sucrose } \\
\text { covalent }\end{array}$ & $\begin{array}{l}0.5 \times \mu \mathrm{m}^{-2} \\
2.5 \times \mu \mathrm{m}_{-2} \\
3.7 \times \mu \mathrm{m}^{-2} \\
18 \times \mu \mathrm{m}^{-2}\end{array}$ & $\begin{array}{l}1.3 \times 100^{-1} \mu \mathrm{m}^{-2} \\
2.6 \times 100^{-1} \mu \mathrm{m}^{-2} \\
4.2 \times 100^{-1} \mu \mathrm{m}^{-2} \\
12 \times 100^{-1} \mu \mathrm{m}^{-2}\end{array}$ & $\begin{array}{l}37 \text { fold improvement } \\
\text { in phage } \\
\text { immobilization yielded } \\
\text { only a } 9 \text { fold } \\
\text { improvement in } \\
\text { bacterial capture }\end{array}$ & [82] \\
\hline Glass slide & $\begin{array}{l}\text { PR772 } \\
\text { T4 } \\
\text { MS2 } \\
\text { PRD1 } \\
\text { P22 }\end{array}$ & $\begin{array}{l}\text { symmetric } \\
\text { tailed } \\
\text { short tail } \\
\text { symmetric } \\
\text { short tail }\end{array}$ & $\begin{array}{c}\text { E. coli } \\
\text { S. Typhimurium } \\
\text { E. coli } \\
\text { E. coli } \\
\text { S. Typhimurium } \\
\text { S. Typhimurium }\end{array}$ & covalent & n.a. & $\begin{array}{l}2.5 \times 10^{5} \mathrm{~cm}^{-2} \\
6.6 \times 10^{5} \mathrm{~cm}^{-2} \\
3.2 \times 10^{5} \mathrm{~cm}^{-2} \\
6.1 \times 10^{5} \mathrm{~cm}^{-2} \\
8.6 \times 10^{5} \mathrm{~cm}^{-2} \\
3.2 \times 10^{5} \mathrm{~cm}^{-2}\end{array}$ & $\begin{array}{l}\text { Symmetric and short } \\
\text { tailed phage more } \\
\text { efficient in capturing } \\
\text { bacteria }\end{array}$ & [146] \\
\hline Silica beads & $\begin{array}{l}\text { AG2 } \\
\text { AG8 } \\
\text { AG11 }\end{array}$ & tailed & $\begin{array}{l}\text { E. coli } \\
\text { S. enteritidis } \\
\text { S. boydii }\end{array}$ & physisorption & n.a. & n.a. & $\begin{array}{l}\text { Phage immobilization } \\
\text { improved } 3.5 \log \text { units }\end{array}$ & [69] \\
\hline
\end{tabular}




\begin{tabular}{ccccccc}
\multicolumn{9}{c}{ L. innocua } & & by electrostatic \\
attraction
\end{tabular}

n.a.: not available, $* \%$ surface coverage, ${ }^{\dagger} \%$ of initial $\mathrm{pfu} / \mathrm{mL}$ or $\mathrm{cfu} / \mathrm{mL}$ 
Table 3. Phage-functionalized surfaces for antimicrobial surfaces and coatings

\begin{tabular}{|c|c|c|c|c|c|c|}
\hline Surface & Phage & $\begin{array}{l}\text { Phage } \\
\text { geometry }\end{array}$ & Host organism & $\begin{array}{c}\text { Means of } \\
\text { immobilization }\end{array}$ & $\begin{array}{c}\text { Antimicrobial } \\
\text { effect }\end{array}$ & Reference \\
\hline & $\mathrm{T} 4$ & & E. coli & & & \\
\hline $\begin{array}{l}\text { Hydrogel } \\
\text { coating }\end{array}$ & $\begin{array}{l}\text { coli- } \\
\text { proteus } \\
\text { phage }\end{array}$ & tailed & P. mirabilis & physisorption & $\begin{array}{l}99 \% \text { biofilm } \\
\text { reduction }\end{array}$ & [54] \\
\hline $\begin{array}{l}\text { Hydrogel } \\
\text { coating }\end{array}$ & BP 456 & n.a. & S. epidermidis & physisorption & $\begin{array}{l}2.34-4.47 \log \\
\text { CFU cm }{ }^{-2} \\
\text { reduction }\end{array}$ & [7] \\
\hline $\begin{array}{c}\text { Hydrogel } \\
\text { coating }\end{array}$ & M4 & n.a. & P. aeruginosa & physisorption & $\begin{array}{l}3 \log \mathrm{CFU} \mathrm{cm} \mathrm{cm}^{-2} \\
\text { reduction }\end{array}$ & [55] \\
\hline $\begin{array}{l}\text { Cellulose } \\
\text { membranes }\end{array}$ & $\begin{array}{l}\text { phage } \\
\text { cocktail }\end{array}$ & tailed & $\begin{array}{l}\text { L. monocytogenes } \\
\text { E. coli }\end{array}$ & physisorption & $\begin{array}{l}1.5-5 \log \mathrm{CFU} / \mathrm{g} \\
\text { reduction }\end{array}$ & {$[68]$} \\
\hline Glass slide & PRD1 & symmetric & S. Typhimurium & covalent & $\begin{array}{c}\text { Bacterial } \\
\text { membrane } \\
\text { disruption at } 35 \\
\text { min }\end{array}$ & [146] \\
\hline Gold & BP14 & tailed & S. aureus & $\begin{array}{l}\text { physisorption } \\
\text { chemisorption }\end{array}$ & $\begin{array}{c}12.5 \% \text { bacterial } \\
\text { growth reduction } \\
37.5-99.9 \% \\
\text { bacterial growth } \\
\text { reduction } \\
\end{array}$ & [76] \\
\hline
\end{tabular}

n.a.: not available 
Table 4. Stability of phage-functionalized surfaces in response to various environmental conditions

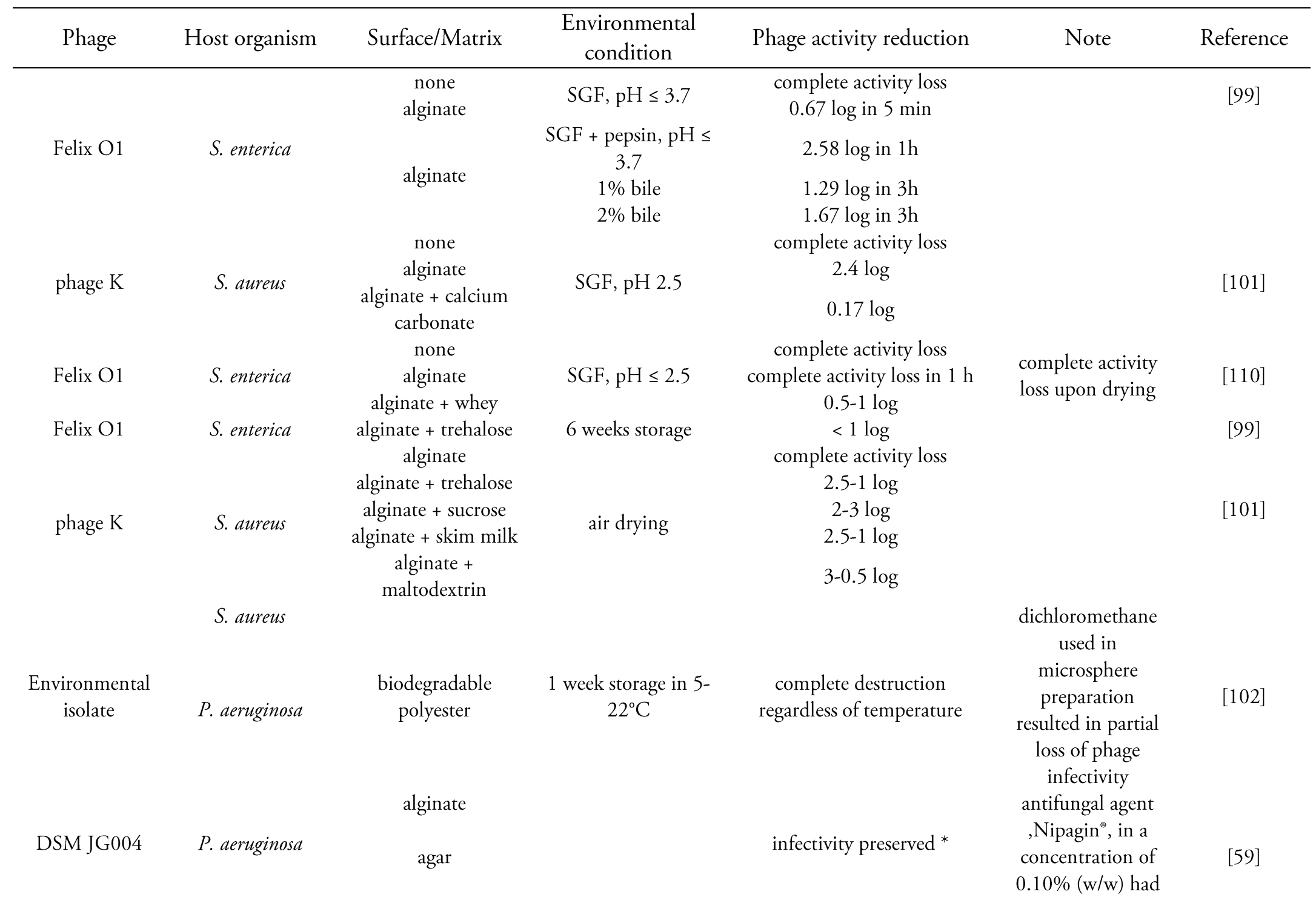




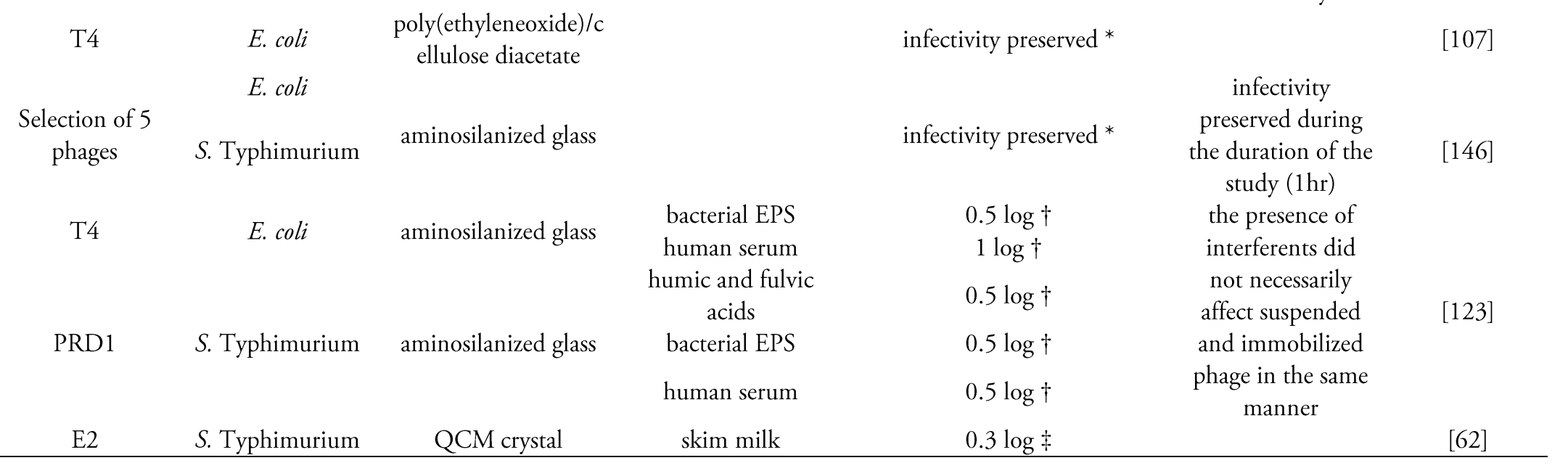

EPS: extracellular polymeric substances

SGF: simulated gastric fluid

* no quantitative data available

${ }^{\dagger}$ reduction reported in terms of bacterial capture

* reduction in QCM signal 